\title{
Trade Gains from Legal Rulings in the WTO Dispute Settlement System
}

\author{
WONKYU SHIN * \\ Center for International Development, Korea Development Institute \\ DUKGEUN AHN* * \\ Graduate School of International Studies, Seoul National University
}

\begin{abstract}
Using bilateral trade data on WTO disputes from 1995 to 2010 within the framework of multilateral trade, this paper empirically investigates whether legally winning a WTO dispute leads to actual trade gains. This study helps to illuminate the efficacy of the WTO dispute settlement system and to understand the role of the system as an institutional device for promoting multilateral trade liberalization. Assessing differential effects of the WTO dispute settlement rulings and the legal status of participants, this paper examines how trade gains are created and distributed among WTO members. Our empirical findings suggest that winning a legal dispute contributes to multilateral trade liberalization, not merely by rectifying trade problems for prevailing complainants but more so by providing better market access for all WTO members. This result reaffirms that the WTO dispute settlement system fulfills its purpose as a regulatory instrument for promoting multilateralism and market competition.
\end{abstract}

\section{Introduction}

As of November 2016, a total of 514 trade dispute cases have been brought to the WTO Dispute Settlement Body (DSB). This large number of cases suggests that the DSB is the central functionary of the WTO system. Another significant factor in evaluating the success of the WTO DSB is the system's judicial efficacy against trade-restrictive measures: whether the legal rulings of the DSB lead to trade liberalization. If the judicial efficacy of the WTO dispute settlement lies in resolving problems by winning a case against a country that has violated the rules of

\footnotetext{
*Email: wkshin@kdi.re.kr

**Email: dahn@snu.ac.kr

We are very grateful to Jeffrey Bergstrand, Mario Crucini, Sungjoon Cho, Jee-Hyeong Park, Patrick Messerlin, Taeho Bark, Jung Hur, Joo Yeon Sun, Walter G. Park, Krzysztof J. Pelc, Aaditya Matto, Ana M. Fernandes, Wonhee Lee, and Tom Norris for helpful discussions and comments on earlier drafts. We also deeply appreciate Alan Winters and anonymous reviewers for their insightful suggestions. We recognize the research support by the Ministry of Education of the Republic of Korea and the National Research Foundation of Korea (NRF-2015S1A3A2046224) and Seoul National University Asia Center (SNUAC-2015-008).
} 
international trade, it is crucial to examine the nexus between outcomes of legal resolutions and economic consequences (Bown, 2004, Bown and Reynolds, 2017, Chaudoin et al., 2016; Kucik, and Pelc, 2016; Shin and Ahn, 2017). The central idea of this argument, drawing on Bagwell and Staiger (1999, 2001), is that GATT/WTO agreements rely on their self-enforcing nature to address the 'terms-of-trade externalities' problem. As such, dispute settlements, especially legal wins, lead respondents to liberalize their markets in response to recommendations of the WTO DSB.

In relevant empirical studies, however, this trade effect of the WTO DSB has not yet been thoroughly explored; literature considering the multilateral effects of the legal outcomes remains scarce. Previous studies, such as Bown (2004, Bown and Reynolds, 2017), conduct this type of empirical study, employing 'bilateral trade liberalization' as a measure to study the effects of GATT/WTO dispute settlements. This empirical framework focuses on changes in trade flows between disputing countries (respondent versus complainant); however, it overlooks the 'multilateral nature (MFN: Most Favored Nation) of the WTO DSB effect' which creates an adjustment in the respondent's imports from all WTO members, as opposed to imports merely from direct legal stakeholders, such as the complainants and third party countries.

In this article, we empirically investigate the impact of the WTO DSB on trade flows. Specifically, the key question is whether the WTO DSB's judicial system enhances multilateral trade liberalization by enforcing the removal of trade restrictive measures. Using HS 6-digit product-level trade data for WTO disputes from 1995 to 2010, we analyze the trade effects of WTO DSB legal rulings within the framework of multilateral trade flows. Firstly, we test whether WTO DSB legal proceedings and successful resolutions lead to an increase in a respondent's overall imports of disputed products. Secondly, we question to whom and to what degree, legal wins in the WTO DSB bring economic gains, analyzing exporter groups according to their legal position in the dispute (complainant, third party, or non-participants). Considering various time-invariant and variant variables subject to disputing parties, timings of dispute settlement, and implementation, our econometric testing separates out economic gains following the completion of DSB proceedings.

Our findings suggest that a legal win through the WTO DSB raises, on average, the respondent's imports following implementation of the rulings. However, a legal win might be seen as a Pyrrhic victory ${ }^{1}$ for the legal contestant, as relatively lesser gains are accrued to complainants and third parties than to non-participants. Legal wins in the DSB provide greater trade gains for non-participant WTO members, particularly by opening new opportunities for entry into a market. Overall,

1 A Pyrrhic victory in the context of our paper can be expressed as 'winning a battle (legally) but losing the war (economically)'. This is because, for the victor, such victory entails the loss of relative market shares due to the free riding of new exporters that reap benefits while avoiding the legal costs of dispute participation. 
however, legal wins do not represent 'hollow victories' as the world economy benefits from the rulings and further damage against complainants is limited. For instance, DSB rulings against respondents lead to trade gains by removing specific trade barriers for complainants. There certainly is valid motivation to pursue legal proceedings, if the individual complainant has high existing export levels to protect and stands to earn absolute gains large enough to offset the cost of the proceedings following a legal victory.

The subsequent section briefly reviews the relevant literature and discusses the theoretical foundation for the empirical analysis. The third section presents an estimation strategy and econometric method. The fourth section explains data, variables, and their statistical characteristics. In the fifth section, estimation results and robustness checks are presented. The paper concludes with a section devoted to possible policy implications.

\section{Judicial efficacy of the WTO DSB: legal wins promote trade after all}

In theory, trade gains should be effectively realized from the DSB's legal rulings against respondents' trade-restrictive measures. The WTO agreements though, as international contracts, are endogenously incomplete due to various uncertainties and country-specific contingencies (Maggi and Staiger, 2011). Nevertheless, many believe that the WTO DSB and its rulings fill up lacunae in the endogenous incompleteness of the judicial WTO system (Ceva and Francasso, 2010; Keck and Schropp, 2008; Maggi and Staiger, 2011). In practice, various factors affect dispute settlements and enforcement of rulings for subsequent economic outcomes under the WTO DSB. Bown (2009) points out that the self-enforcing nature of the WTO DSB works only when there are implicit or explicit threats of enforcement against contravening parties; and self-enforcement is not the result of conduct, but rather the result of enforcing power arising from the specificities of a dispute (Park, 2016).

Previous empirical studies analyze whether a WTO dispute ruling achieves a distinguishable judicial efficacy in trade flows (Bown, 2004; Bown and Reynolds, 2015, 2017; Chaudoin et al., 2016; Shin and Ahn, 2017). From a complainant's point of view, the expansion of an export market through the removal of trade restrictive measures could be the fruition of participating in judicial proceedings of the dispute. Therefore, an increase in exports purely led by the legal rulings, particularly legal wins, of dispute settlement may be a useful criterion for determining the judicial efficacy of the WTO DSB.

The pioneering work of Bown (2004) employs actual trade data to demonstrate a link between economic success and GATT/WTO DSB's legal outcomes. Identifying import penetration as the key trade liberalization effect for measuring changes in the growth rate of imports before and after the WTO panel rulings, Bown (2004) finds that the effects of WTO DSB's rulings are somewhat limited. More recently, Bown and Reynolds (2017) examine whether outcomes of WTO 
dispute negotiations fit with Bagwell and Staiger's (1999) terms-of-trade theory. They empirically show that larger post-dispute import volume outcomes are associated with products that have smaller terms-of-trade losses, larger pre-dispute trade volumes, larger import demand, and smaller foreign export supply elasticities. This result was presented to show that 'trade dispute negotiations' potentially address the problem of the terms-of-trade externality. These studies are important as they provide an initial guideline for empirical analysis of the economic effect of dispute settlements.

Most empirical studies on this topic have focused on the economic effects within the framework of bilateral trade liberalization using dyadic trade data between disputing countries. These studies investigate the determining factors that explain the changes in trade flows 'between complainants and respondents.' Our approach, however, considers dyadic relationships 'between respondents and all WTO members,' including both third parties and small/least-traded or even zero-exporters as possible beneficiaries of liberalization. We highlight market re-adjustments in trade flows from non-disputing parties - trade creation from extensive margin growth - a novel element in the econometric analysis of the WTO DSB effect. It is important to properly evaluate the efficacy of the dispute settlement system in relation to possible externalities. The rulings of the WTO DSB, by non-discriminatory free-trade principles, are applied against bilateral protectionist measures, but they work to promote freer multilateral trade. Therefore, we should assess the efficacy of WTO DSB rulings by considering their impact on all WTO member countries under the MFN obligation and possibly to even non-members.

Our research framework identifies the following two empirical questions. First, do the legal rulings of the WTO DSB promote overall imports in respondents' markets? Second, whose market access is more enhanced as a result of legal rulings? For these questions, we investigate MFN externalities of the WTO DSB's rulings (Bagwell and Staiger, 2005; Kucik and Pelc, 2016; Ludema and Mayda, 2009). Also, the main drivers of 'gains from rulings' are explored: whether the trade gains are due to the growth of the intensive margin (growth in goods previously traded by major exporters) or the extensive margin (growth in goods previously traded by small or new exporters).

A few studies have investigated the effect of the DSB on trade liberalization by considering the multilateral dimension of the WTO DSB effects. Some existing studies have focused on the role of a third party and its motivation to participate in the dispute, as well as its influence on the negotiations or rulings of the DSB during the dispute (Busch and Reinhardt, 2006; Bechtel and Sattler, 2015; Davis and Bermeo, 2009). Notably, Kucik and Pelc (2016) analyze the benefits of the WTO DSB at the global level; however, their research focuses on measuring the cost of privacy and the distributional bias in trade outcomes according to settlement type. Chaudoin et al. (2016) also study the net liberalization effect of DSB and conclude that disputes are weakly associated with an increase in total trade levels. Their findings are based on the comparison between overall increases in 
bilateral trade flows of the disputed products and non-disputed products in the wake of a dispute.

Our analysis does not aim to verify the effectiveness of the WTO DSB per se but instead seeks to examine the trade effects of WTO dispute settlement by providing new perspectives on its multilateral liberalizing effects, along with empirical evidence pertaining to trade flow dynamics before and after the dispute settlement. We analyze not only bilateral patterns of trade change before and after WTO disputes, especially in cases where DSB rules against the respondent and its trade measure, but also the impact of rulings on global trade by comparing trade impacts for different disputing parties - complainants and third parties as well as non-participants. This approach helps to provide a comprehensive basis for judging the efficacy of the WTO DSB and understanding the economic utility of the DSB system.

\section{Estimation strategy and econometric model}

\subsection{Institutional background and initial observation of the data}

In general, there are two institutional mechanisms for settling a dispute under the WTO DSB. The first is DSB legal proceedings via panel and Appellate Body (AB) procedures. The second is non-litigious bilateral consultations for seeking a mutually agreed solution, official withdrawal, or termination. From a functional perspective, it is insignificant to promote one mechanism as superior to another, as long as member countries adhere to the WTO DSB process instead of taking unilateral actions. From a practical perspective, however, complainants' main concerns are whether DSB resolutions have a significant effect or not.

The DSB proceedings have four broad stages: consultation between disputing parties, the establishment of a panel, adoption of panel or $\mathrm{AB}$ reports, and implementation of the legal rulings. However, when considering the economic analysis of trade flow and economic impact, the more relevant points of a dispute process are (i) before the dispute; and (ii) after dispute initiation upon an official consultation request. The first phase refers to the point when a complainant detects initial evidence of changes to the value or volume of its exports to the respondent. The evidence is usually observed within a year (or shorter in monthly and quarterly data) before a dispute initiation.

The second phase starts from the year of the dispute initiation. This period may also be divided into two periods: (i) the period encompassing the consultation request and settlement before further legal proceedings, and (ii) the period during which a legal dispute officially occurs, and the implementation of the recommendation of the WTO DSB's ruling is carried out. During the consultation period, the WTO DSB provides opportunities for the disputing parties to come together for bilateral negotiation. Prior to a fully fledged legal dispute, the consulting members can adjust their stances on the case. During this period, a case may be 
closed if the complainant agrees to withdraw. If the parties fail to reach a mutually agreeable solution, the complainant can proceed to establish a panel. At this point, according to WTO DSB Article 4.11, third parties may join the dispute by request via a process set out in Article 10. The precondition for joining the dispute, however, is the possession of a substantial interest in the matter, and written submissions by the third parties to the panel are taken into consideration. Regarding trade flow, any parties participating in a dispute settlement, including third parties, may experience significant changes in trade of disputed products throughout the dispute settlement process. However, we should not overlook trade growth made by non-participants through new market entry (i.e., extensive margin growth) and market expansion (i.e., intensive margins) following the removal of trade restrictive measures.

Table 1 presents preliminary information on the trade flow changes of disputed products. Specifically, it shows the changes in mean values of respondents' imports of the disputed products per WTO member country for various periods before dispute initiation and after dispute termination. Trade flows are divided into two broad periods: (i) $\operatorname{PRIOR}_{(\tau-t)}$ denotes years before dispute initiation $(\tau)$ and (ii) $\operatorname{POST}_{(T+t)}$ denotes years following dispute completion $(T)$. For example, the third column of the table $\left(\operatorname{PRIOR}_{(\tau-1 \sim 2)}\right)$ shows the average value of the disputed product imports for respondents prior to the initiation of a dispute; $(\tau-1 \sim 2)$ indicates the average level of these imports two years before the dispute initiation. The fourth, fifth, and sixth columns - $\operatorname{POST}_{(T+1 \sim 2)}, \operatorname{POST}_{(T+2 \sim 3)}$, and $\operatorname{POST}_{(T+1 \sim 3)}-$ represent first- and second-year, second- and third-year, and first- to third-year average imports following a dispute's completion $(T)$. In order to see import changes over time, we calculate the import growth rates (percentage change) of respondent countries in the parentheses for post periods, $(T+1 \sim 2),(T+2 \sim 3)$, and $(T+1 \sim 3)$, which are respectively compared against mean import values $1 \sim 2$ years before the dispute initiation $(\tau-1 \sim 2)$. In the POST years, mostly due to new entries to the WTO membership, the number of non-participants changes over time. As such, the number of overall exporting countries to respondents fluctuates accordingly. This table further breaks down these import values according to three groups (complainant, third party, and non-participant) and five categories of final DSB decisions (legal win, mutually agreed, non-legal win, withdrawal, and dropped with no further proceedings).

This table illustrates some interesting descriptive characteristics. First, the number of legal participant countries is much smaller than the number of non-participants, but their trade in the disputed products is, on average, much larger. This suggests that the disputed import markets have a somewhat monopolistic structure, meaning that the market has potential growth and welfare in terms of the world economy when the market is more open. Second, as expected, a complainant group has the greatest economic interest in the disputed products while a third party has a substantial interest as well, second only to the complainant group. Third, the average trade quantities are larger for legally contested cases among 
Table 1. Trade flow changes pre-and post-DSB dispute and outcomes by group Unit: Million USD (Percentage change: $\% \Delta$ )

\begin{tabular}{|c|c|c|c|c|c|}
\hline \multirow[b]{2}{*}{ Group } & \multirow[b]{2}{*}{ WTO DSB outcome } & \multirow{2}{*}{$\begin{array}{l}\text { PRIOR } \\
(\tau-1 \sim 2)\end{array}$} & \multicolumn{3}{|c|}{ POST (years after the dispute is completed) } \\
\hline & & & $(T+1 \sim 2)$ & $(T+2 \sim 3)$ & $(T+1 \sim 3)$ \\
\hline \multirow{6}{*}{$\begin{array}{l}\text { All groups } \\
\text { (WTO members) } \\
\quad N=76,661-115,424\end{array}$} & Overall (mean) & 48 & $67(41.6)$ & $71(50.0)$ & $69(45.8)$ \\
\hline & Legal win & 60 & $86(42.2)$ & $96(58.5)$ & $91(51.1)$ \\
\hline & Mutually agreed & 42 & $75(79.9)$ & $71(70.4)$ & $73(74.4)$ \\
\hline & Non-legal win & 160 & $215(34.0)$ & $220(37.0)$ & $216(34.9)$ \\
\hline & Withdrawal & 44 & $53(20.6)$ & $60(36.9)$ & $57(29.6)$ \\
\hline & Dropped & 24 & $28(17.8)$ & $30(23.7)$ & $29(19.9)$ \\
\hline \multirow{6}{*}{$\begin{array}{r}\text { Complainants } \\
N=648-976\end{array}$} & Overall (mean) & 892 & $1,097(23.0)$ & $1,161(30.1)$ & $1,124(26.0)$ \\
\hline & Legal win & 1,101 & $1,437(30.6)$ & $1,553(41.1)$ & $1,493(35.6)$ \\
\hline & Mutually agreed & 427 & 704 (64.7) & $675(58.0)$ & $678(58.7)$ \\
\hline & Non-legal win & 2,983 & $3,440(15.3)$ & $3,432(15.1)$ & $3,414(14.5)$ \\
\hline & Withdrawal & 1,827 & $1,729(-5.4)$ & $2,039(11.6)$ & $1,892 \quad(3.6)$ \\
\hline & Dropped & 515 & $547 \quad(6.1)$ & $570(10.8)$ & $555 \quad(7.8)$ \\
\hline \multirow{6}{*}{$\begin{array}{l}\text { Third parties } \\
N=2272-3412\end{array}$} & Overall (mean) & 573 & $823(43.5)$ & $872(52.0)$ & $846(47.5)$ \\
\hline & Legal win & 554 & $828(49.4)$ & $891(60.8)$ & $860(55.2)$ \\
\hline & Mutually agreed & 259 & 411 (58.9) & $386(49.2)$ & $395(52.7)$ \\
\hline & Non-legal win & 1,412 & $1,914(35.6)$ & $2,017(42.8)$ & $1,949(38.0)$ \\
\hline & Withdrawal & 78 & $133(69.4)$ & $129(64.7)$ & $131(66.7)$ \\
\hline & Dropped & 901 & $981 \quad(8.8)$ & $1,006(11.6)$ & $988 \quad(9.7)$ \\
\hline \multirow{6}{*}{$\begin{array}{l}\text { Non-participants } \\
\quad N=73,745-111,042\end{array}$} & Overall (mean) & 25 & $35(42.7)$ & $37(50.7)$ & $36(47.1)$ \\
\hline & Legal win & 23 & $29(29.1)$ & $34(52.1)$ & $32(42.6)$ \\
\hline & Mutually agreed & 33 & $60(84.2)$ & $57(74.7)$ & $59(79.1)$ \\
\hline & Non-legal win & 82 & $110(34.7)$ & $110(34.9)$ & $110(34.5)$ \\
\hline & Withdrawal & 29 & $39(33.6)$ & $44(51.3)$ & $42(43.7)$ \\
\hline & Dropped & 15 & $18(23.8)$ & 19 (30.9) & $18(26.3)$ \\
\hline
\end{tabular}

Note: The real import value is our dependent variables for the regression analysis.

' $N$ ' is the number of observations for each group over the five year period $(\tau-2, \tau-1, T+1, T+2$, and $T+3$ ) where $\tau$ denotes the point of dispute initiation and $T$ denotes the point of dispute completion. The variations between the three groups (complainant, third-party, and non-participant) and within groups before dispute initiation (PRIOR: $\tau-1 \sim 2$ ) and after dispute completion (POST: $T+1 \sim 3$ ) provide the statistical grounds for our subsequent regression analysis.

'All Groups' indicates all WTO member countries. 'Complainants' are countries that have raised a dispute to the WTO DSB. 'Third parties' are countries that join the WTO DSB proceedings due to their substantial interest in the outcome. 'Non-participants' are countries not directly participating in the dispute but that may become potential beneficiaries of the outcome.

To see import changes over the dispute period, the import growth rates (percentage change from baseline: $\% \triangle)$ of respondent countries are calculated in the parentheses for post periods such as $(T+$ $1 \sim 2),(T+2 \sim 3)$, and $(T+1 \sim 3)$ and are compared against mean import values 1-2 years before the dispute initiation $(\tau-1 \sim 2)$. In the POST years, mostly due to new entries into the WTO, the number of non-participants varies. As such, the number of overall exporting countries to respondents fluctuates accordingly. 
the DSB proceedings. This is consistent with the fact that WTO legal proceedings are likely to be taken up and pursued to tackle problematic measures that protect high-stakes import markets. Fourth, the table shows a relatively smaller increase in the exports of complainants between the pre-dispute and post-dispute periods following a legal victory than that of other participant groups. Lastly, however, in mutually agreed cases, the exports of all three groups increase substantially in post-dispute period.

\subsection{Estimation strategy}

We employ two types of variations to detect the economic effect, especially in terms of imports, of the WTO DSB. One is a time variation to check economic impact before and after a dispute. The other is a cross-sectional variation between disputing parties, including third parties and non-participants. The differences in trade value before and after a WTO dispute measured for disputing parties are compared to those measured for non-participants. In addition to combining two dimensions of variation, cases can be divided into those where complainants (1) win, (2) lose, and (3) officially withdraw, and those where disputing parties are (4) settled with a mutually agreed solution. Lastly, cases that are (5) dropped with no further proceedings are used as a reference for the four other dispute outcomes.

In contrast to previous studies that address the trade effects between disputing parties, our analysis shows changes in bilateral import flows of respondent countries with respect to all exporting countries for the period spanning from consultation stages of disputes to implementation of rulings. An empirical estimation of bilateral trade flows for all countries allows a more comprehensive analysis of the economic impact of legal rulings. Since controlling for other factors that may affect respondents' trade is critical in this comprehensive econometric analysis, this study adopts the following analytical strategies.

First, we include three country-specific effects to fix unobserved characteristics specific to (i) respondents, (ii) complainants, and (iii) WTO members by using corresponding dummies in the regression estimation. The main idea behind including respondent and complainant country-specific fixed effects is due to the differences in time-invariant characteristics that one can observe in their legal roles (one dummy as respondent and another as complainant). 'Member' dummy for each WTO member country is included to capture fixed country characteristics, independent of their position in any dispute. The member dummy controls for other unobserved individual country-specific characteristics, which are related to different economic and political conditions (Busch et al., 2009; Sattler and Bernauer, 2011; Shin et al., 2016). Examples of these three fixed effects include the frequency and capacity of how a country makes use of the WTO DSB, as well as income, average trade level, size, and retaliatory power.

Second, we consider bilateral-pair effects to control for the bilateral economic/ political relationship between complainants and respondents. These pair effects 
control any particular tendency formed by the specific relations between complainants and respondents. For example, one pair may have trade disputes more or less often than others due to special political relations (e.g. FTA relations or aid donorrecipient relations) or geographical characteristics (e.g. cultural traits and physical distance) specific to the pair (Ahn and Shin, 2011; Baier and Bergstrand, 2007; Bown, 2009; Shin et al., 2016).

Third, we also take year fixed effects into account to capture any macroeconomic trends in the world trade flow of the disputed products. During the dispute period, there could be time-specific factors such as significant changes in oil prices, financial crises, economic booms, and exchange rate fluctuations that severely influence the dependent variable. Thus, year fixed effects are included to control for these macroeconomic elements.

Fourth, agreement effects are added to control for case-specific factors subject to WTO Agreements. The effects can capture the specificity of different agreements, which do not vary by respondent. It is important to note that the trade levels differ depending on the specific agreements covered. For example, disputes concerning non-tariff barriers such as technical regulations, sanitary and phytosanitary measures, or domestic taxes may relate to smaller and less concentrated trades. On the contrary, disputes dealing with specific tariffs or trade remedy measures such as anti-dumping and countervailing actions tend to relate to greater trade levels as trade reductions become evident.

Fifth, industry fixed effects are included for the industrial characteristics of products at issue. The economic effects of legal rulings are also critically dependent on the industry. Protective measures on industries that are domestically and politically sensitive, such as agriculture, are inclined to show smaller economic effects. In contrast, industries that are less sensitive in this respect can produce larger economic benefits to complainants because it is easier and quicker to remove disputed measures.

Sixth, we carefully address issues concerning the time points. Various time points are used to account for the time-delaying of DSB proceedings and their durational effects. For example, a losing respondent needs a substantial amount of time to implement the recommendations of the WTO DSB; thus, we consider time frames from the year of the DSB decision report to the completion year of implementing the DSB rulings in the post-dispute analysis. On the other hand, we also need to consider the proper duration time of the DSB effect since its inception, which may fade in or out during market adjustment. Factoring into account various time treatment dummies with lags based on the duration times, we investigate the impact of WTO DSB outcomes on trade flow changes. This approach helps to capture the empirical effect of the WTO DSB outcomes, rather than simply detecting the changes in trade flows of disputed products.

Lastly, this paper addresses concerns over the possible endogeneity bias facing estimation for the DSB effect, noting that WTO disputes and DSB outcomes are not random or strictly exogenous. Reverse causality aside, even differencein-difference estimation with country fixed effects is not a perfect solution for 
this endogeneity problem (Conconi et al., 2017). The omitted unobservable timevarying variables are arguably the most significant factors contributing to a potential endogeneity bias (Baier and Bergstrand, 2007). For example, when a DSB outcome is anticipated, trade flows are likely to be adjusted for many other reasons apart from the DSB effect. Particularly, this re-adjustment is driven not only by treatment per se but also by changes of time-varying conditions associated with each respondent and its trade partners.

This estimation technique can be understood as country-and-time fixed effects to account for the changes in the unobservable multilateral resistance terms in the panel gravity modeling of Baier and Bergstrand (2007). For the treatment of the presence of endogeneity, we make our analysis valid and robust with the full use of fixed effects for time-invariant and time-varying variables using difference-in-difference (differenced) estimations while accommodating the anticipatory/reactionary behaviors of markets using various timings of the dispute to the regression models. Controlling the timings and time-varying situations in respondent markets can crucially help to alleviate the concerns of endogeneity bias. $^{2}$

In summary, we establish an empirical estimation model designed to explore the differential effects of WTO disputes on the dependent variable. The model considers DSB status, case, time, group-specific differences, and timing while controlling for other unobservable factors that affect the variables of interest, employing various fixed effects as explained above. The first equation is used to identify the economic benefit of DSB's legal proceedings, regardless of the different roles of WTO member countries in a disputed case (i.e., treating all countries symmetrically).

$$
\begin{aligned}
& \ln \left(I_{i j, t(\tau, T)}\right) \\
& =\beta_{0}+\beta_{1} \text { WTODS_POST }_{i t}+\beta_{2} \text { DSB }_{i t}+\beta_{12}\left(\text { WTODS_POST }_{i t} \times \text { DSB }_{i t}\right) \\
& \quad+\delta_{r(t)}+\delta_{c}+\delta_{j(t)}+\delta_{r c}+\delta_{\text {Agreement }}+\delta_{H S \_i n d u s t r y}+\delta_{y e a r}+\epsilon_{r j t}
\end{aligned}
$$

where the dependent variable, $\ln \left(I M_{i j, t \tau, T)}\right)$, is the logarithm of 'Real Import (RIM)' of the disputed product and countries in year $t(\tau, T) \in\{\tau-2, \tau-1, \tau, T, T+1, T+2$, $T+3\} ; i$ indicates dispute cases where each case corresponds to one respondent $r$ with the dispute-related product(s) $p$ such that $i=(r, p) ; j$ indicates trading partner countries with respondent $r$ whose exports are product(s) $p$ in year $t$ and $j \in\{$ complainant, third party, others (non-participant countries) $\}$-all WTO

2 Along with time-varying country fixed effects, we may consider time-varying industry-specific fixed effects. The industry-year fixed effects account for time-varying product features, such as costs of production and transaction. In addition, these fixed effects absorb the effect of technology and business cycles specific to disputed industries. Given the current estimation structure, however, it is impractical to implement a regression with so many dummy variables, thus we select country-time over industry-time fixed effects. 
member countries ' $j$ ' varying by year ' $t$ '. ' $\tau$ ' indicates the year when a dispute was initiated while ' $T$ ' refers to the year when a dispute was completed. In our estimation model, all missing observations are replaced with zeros, such as $\ln (1+$ real imports), assuming that all non-reported information for trade values at the HS 6-digit sectoral level is zero (Helpman et al., 2008). Following the heterogeneous firm model (Helpman et al., 2008) to explain zero trade flows across countries with fixed costs of exporting and variable trade costs, we assume that zero trade is associated with high bilateral fixed costs of trade. In the context of our analysis, zero imports of disputed products in respondent countries and asymmetric trade flows between country pairs are products of trade barrier costs stemming from allegedly protectionist measures by respondents.

WTODS_POST $_{i t} \equiv$ WTODS_POST $_{(T+t)}$ refers to the time dummy after the WTO DSB's final decision is made; taking a value of 1 when $t=0,1,2$ and/or 3 . We use four period dummies to capture DSB timing effects on imports as opposed to just the base period dummy; taking a dummy which has value 1 in years $T 0, T+1$ and $T+2$ for $(T 0 \sim 2)$, in $T+1$ and $T+2$ for $(T 1 \sim 2)$, in $T+2$ and $T+3$ for $(T 2 \sim 3)$, and in $T+1, T+2$, and $T+3$ for $(T 1 \sim 3)$. To test different delayed and timing effects, the regression models use various lagged time variables with different time points. For example, $(T+1 \sim 2)$ refers to a period of one to two years (1 2 years) after a dispute completely ends in WTODS_POST $(T+1 \sim 2)$. To consider a two-year time lag for the effect, $(T+2 \sim 3)$ is used to specifically study a period between two and three years after the DSB's final decision. $(T+1 \sim 3)$ is used to denote a period spanning from the first year to the third year following a dispute's conclusion. ${ }^{3}$

DSB is a dummy variable for measuring the result of WTO DSB proceedings. $\mathrm{DSB}_{i}$ indicates one of the final statuses of a WTO dispute that has concluded for a specific respondent product $i$. The WTO disputes fall into five non-overlapping possible DSB outcome categories: LW - legal win; MA - mutually agreed or settled; Non-LW - 'not guilt'; WD - withdrawn; and DROP - dropped. These categories are classified according to official indications by the WTO DSB as 'Current Status' of a dispute. There are a small number of subsets under 'dropped' such as 'no further proceeding,' 'authority for panel lapsed,' and so on. ${ }^{4}$ For example, LW takes the value of 1 if the measures at issue are found to be inconsistent with the

3 In the equation, WTODS_PRIOR $(\tau-t)$, the implicitly included base-period dummy indicates two years before dispute initiation; it takes a value of 0 when $t=2,1$, and $\tau(\tau$ denoting the year of dispute initiation). For example, if a dispute starts in $2005(\tau)$ and ends in $2007(T)$, the time dummy for WTODS_POST $(T 0+1 \sim 2)$ should be WTODS_POST $(2007+1 \sim 2)$; thus, post years are those of 2008 and 2009 and base periods are $2003(\tau-2)$ and $2004(\tau-1)$ as the dispute begins in $2005(\tau)$. In addition, all regression models include a time dummy variable for the initiation year to see if there is any particular time-trend other than that of the use of WTO DSB effects from either the idiosyncratic shocks prior to the WTO dispute or mere consultation request effects.

4 See WTO website for these categories; https://www.wto.org/english/tratop_e/dispu_e/dispu_current_ status_e.htm. 
WTO Agreements (i.e., a WTO DSB case where a complainant wins), and equals 0 otherwise.

The interaction term between DSB and POST $\left(\beta_{12}\right)$ estimates a DSB outcome effect on trade in the post years of DSB, showing whether the WTO DSB's legal ruling actually promotes free trade by increasing overall imports in respondent markets compared to disputes that are initiated but dropped. Under the null that the DSB's legal outcomes (LW, MA, Non-LW, and WD compared to DROP) do not affect imports, $\beta_{12}=0$, the coefficient $\beta_{12}$ estimates the difference in import changes dependent on DSB's outcomes. In $\beta_{12}$ (DSB x POST), particularly when the DSB outcome is LW, the coefficient is expected to be positive because a legal win should have a positive effect on overall import liberalization by removing trade barriers and promoting multilateral free trade. However, $\beta_{12}$ for MA is ambiguous and dependent on whether a mutually agreed solution favors freer trade. It is expected to be negative for mutually agreed cases when disputed trade barriers remain in place.

Furthermore, assuming that the variance of variables differs by times and legal groups (complainant, third party, and non-participant), the following regression framework allows us to examine the economic effects of WTO disputes, depending on the status of DSB outcome and participants ${ }^{5}$ :

$$
\begin{aligned}
& \ln \left(I M_{i j, t(\tau, T)}\right)
\end{aligned}
$$

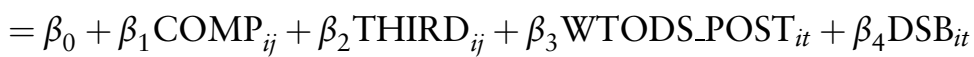

$$
\begin{aligned}
& +\beta_{13}\left(\text { COMP }_{\mathrm{ij}} \times \text { WTODS_POST }_{i t}\right)+\beta_{23}\left(\text { THIRD }_{\mathrm{ij}} \times \text { WTODS_POST }_{i t}\right) \\
& +\beta_{14}\left(\mathrm{COMP}_{\mathrm{ij}} \times \mathrm{DSB}_{\mathrm{it}}\right)+\beta_{24}\left(\mathrm{THIRD}_{i j} \times \mathrm{DSB}_{\mathrm{it}}\right) \\
& +\beta_{34}\left(\text { WTODS_POST }_{i t} \times \text { DSB }_{i t}\right)+\beta_{134}\left(\text { COMP }_{\mathrm{ij}} \times \text { DSB }_{i t} \times \text { WTODS_POST }_{i t}\right) \\
& +\beta_{234}\left(\text { THIRD }_{\mathrm{ij}} \times \mathrm{DSB}_{\mathrm{it}} \times \text { WTODS_POST }_{i t}\right) \\
& +\delta_{\mathrm{r}(\mathrm{t})}+\delta_{\mathrm{c}}+\delta_{\mathrm{j}(\mathrm{t})}+\delta_{\mathrm{rc}}+\delta_{\text {Agreement }}+\delta_{\mathrm{HS} \text { _industry }}+\delta_{\text {year }}+\epsilon_{\mathrm{rjt}}
\end{aligned}
$$

In this equation, the complainant and third party dummies are expressed as $C O M P_{i j}$ ( 1 if a country holds the status of complainant(s) in the dispute, 0 otherwise), THIRD $D_{i j}$ ( 1 if a country holds the status of third party, 0 otherwise) respectively in order to distinguish the role-specific characteristics of affected groups in each dispute case $i$. Compared to equation (1), equation (2) highlights a distribution of the DSB effect

5 This type of regression form is used in policy analyses (see Donald and Lang, 2007; Imbens and Wooldridge, 2007, 2009 for an overview and recent advances of DD methods). This regression equation is a saturated type of DDD estimator that can be proved analogous to the DD case. 
in POST dispute periods (WTODS_POST x DSB) by legal groups and differentiates expected DSB gains according to each country's legal role in the dispute.

The second-level interactions act as a control for changes between different times and within groups. $\beta_{13}$ shows the differences in the complainant's exports (i.e., the respondent's imports) before and after the dispute, whereas $\beta_{23}$ measures the corresponding differences of the third parties. $\beta_{14}$ represents the impact of a dispute outcome on the exports of respondents according to the case outcome and $\beta_{24}$ measures the corresponding impact on third parties when cases reach a final resolution. $\beta_{34}$ controls for the general impact on exports (regardless of group) following final DSB outcomes.

Finally, the third-level interactions, $\beta_{134}$ and $\beta_{234}$, capture all variation in imports, specific to the affected groups (relative to other countries) in the affected cases (four DSB outcome cases) in the years after a WTO dispute (relative to before the WTO dispute). Country, group, and case specific covariates, especially the timeinvariant and time-varying characteristics, are included for the respondent $\left(\delta_{r(t)}\right)$, complainant $\left(\delta_{c}\right)$, member $\left(\delta_{j(t)}\right)$, and respondent-complainant pair $\left(\delta_{r c}\right)$ dummies that are fully saturated country-specific fixed effects. Dummies of agreement for 12 agreement categories are denoted as $\delta_{\text {Agreement }}$, and industry dummies for HS 2-digit level are denoted as $\delta_{H S \_i n d u s t r y}$, and separate year dummies for $1995 \sim$ $2010\left(\delta_{\text {year }}\right)$ are included as controls, as discussed above.

\section{Data and variable description}

The dependent variable of this analysis is the change in real imports of respondents, from complainants as well as other WTO member countries, between 1993 and 2015. WTO dispute cases are sampled from 1995 to 2010. However, we use the trade data of $\tau-2, \tau-1, \tau, T, T+1, T+2$, and $T+3$ to factor the actual timing of finalized DSB outcomes into the estimation models. The import data used as the most visible and simple proxy of the economic gains in this context of analysis comes from Bown and Reynolds (2015). This paper matches each dispute to the product at issue by employing six-digit Harmonized System (HS-06) codes. The dispute settlement database is taken from Hoeckman, Horn, and Mavroidis (2008) and builds upon the source utilized from Bown and Reynolds' (2015) paper. The product data are matched with the HS codes after the import values are converted to real imports (2010, constant in million USD) using the IMF's World Import Deflator. It is noted that if the European Union (EU) was a party to a dispute, all countries which held EU membership at the time of the dispute were considered together as one entity.

The dependent variable and explanatory variables are taken from two sources. The dispute outcome, the key variable of this study, often needs to be redefined and constructed to pinpoint empirical effects of DSB decisions; in particular, legal ruling dummies (either won or lost) to represent final decisions in light of WTO obligations by the DSB. 
Although not much different, the dispute data used in this paper supplements the rough classification of the online database and helps to construct the variable for legal wins in a more detailed manner. ${ }^{6}$ Occasionally, legal rulings raise confusion in terms of classification. For example, US-DRAMS (DS99), on the surface, appears to be a winning case for Korea, as the United States was found to be in violation of the WTO rules. However, the AB later reversed the panel's finding on the basis of the evidentiary standard wrongfully adopted by the panel, and consequently allowed the United States to maintain its countervailing duties. Thus, the case should be seen as a losing case for Korea.

In this analysis, newly constructed trade flow data based on Bown and Reynolds (2015) and updated DSB status data are integrated into one data set for the comprehensive econometric test. The important variables in this analysis are the time dummy for the period centered around the years the dispute was formally initiated/ended, the concerned group dummy, and the DSB outcome dummy. As mentioned in Section 3.2 (estimation strategy), the real import value as the dependent variable should be compared to pre- and post-dispute levels (PRIOR: $\tau-2, \tau-1$ versus POST: $T+1 \sim 3$ ). Furthermore, the various time frames following the DSB's outcome $[(T+0 \sim 2),(T$ $+1 \sim 2),(T+2 \sim 3)$, or $(T+1 \sim 3)]$ account for delays in ruling implementation and are used to discover when the legal outcomes begin to result in economic benefits. The durational points are confined to three years after the implementation in order to estimate the valid effect of a WTO dispute (Bown, 2004; Bechtel and Sattler, 2015). While it is true that the effect of the WTO DSB may begin to manifest over a longer period, especially if the dispute or implementation of the panel's recommendation is delayed, such cases are likely to have more noise in the error term and may weaken the robustness and confidence of the regression results. ${ }^{7}$

The complainant and third party dummy variables are adopted from Bown and Reynolds (2015) in order to specify the country group directly involved in the dispute. The agreement dummy (for agreement specific fixed effects) used to control for the characteristics of each agreement at issue is based on Bown and Reynolds (2015) and worldtradelaw.net. Two data sources also provide a guideline for selecting a single 'matter' for each WTO DSB case even if there is no official classification of individual 'matters' for the WTO DSB case. This paper mainly follows the classification system of worldtradelaw.net with minor corrections.

Not all WTO dispute cases between 1995 and 2010 are included as samples of analysis. Following Bown and Reynolds (2015), only 316 out of the total 419

6 The database on the outcomes of the WTO DSB proceedings, which are similar to the data used in this paper, can be found at worldtradelaw.net (http://worldtradelaw.net/databases/violationlist.php).

7 In practice, the responding behaviors of domestic industries (or firms) in disputes make it difficult to capture the pure effect of the WTO rulings. In many cases, the industries tend to take preemptive actions or seek alternative trade-restrictive measures against the expected policy adjustments during the dispute or before the delayed implementation period of the WTO rulings ends (Bütler and Hauser, 2000; Davis, 2012). 
Table 2. Outcome of WTO disputes filed by year, 1995-2010

Unit: Number (\%)

\begin{tabular}{|c|c|c|c|c|c|c|c|}
\hline \multirow[b]{2}{*}{ Year } & \multirow[b]{2}{*}{ Total } & \multicolumn{5}{|c|}{ WTO DSB outcomes } & \multirow[b]{2}{*}{$\begin{array}{l}\text { Av. years of } \\
\text { dispute }\end{array}$} \\
\hline & & Legal-win & $\begin{array}{l}\text { Non- } \\
\text { legal win }\end{array}$ & $\begin{array}{l}\text { Mutually } \\
\text { agreed }\end{array}$ & Withdrawal & Dropped & \\
\hline 1995-2010 & 316 & $116(36.7)$ & $20(6.3)$ & $61(19.3)$ & $13(4.1)$ & $106(33.5)$ & 1.99 \\
\hline First half $_{(1995-02)}$ & 203 & $(32.4)$ & (7.3) & (19.3) & (3.9) & (37.1) & 1.89 \\
\hline Second half $(2003-10)$ & 113 & $(45.3)$ & (5.1) & $(17.9)$ & (4.3) & $(27.4)$ & 2.07 \\
\hline 1995 & 24 & $(29.2)$ & $(12.5)$ & $(37.5)$ & $(4.2)$ & $(16.7)$ & 2.13 \\
\hline 1996 & 28 & $(39.3)$ & $(14.3)$ & $(10.7)$ & $(10.7)$ & $(25.0)$ & 2.89 \\
\hline 1997 & 34 & $(23.5)$ & $(2.9)$ & (35.3) & $(5.9)$ & $(32.4)$ & 1.74 \\
\hline 1998 & 23 & $(34.8)$ & $(0.0)$ & $(8.7)$ & (4.3) & $(52.2)$ & 1.35 \\
\hline 1999 & 21 & $(47.6)$ & $(4.8)$ & $(9.5)$ & $(0.0)$ & $(38.1)$ & 2.67 \\
\hline 2000 & 23 & $(39.1)$ & $(4.3)$ & (8.7) & $(0.0)$ & $(47.8)$ & 2.00 \\
\hline 2001 & 18 & $(11.1)$ & $(16.7)$ & $(22.2)$ & $(0.0)$ & $(50.0)$ & 0.89 \\
\hline 2002 & 32 & $(34.4)$ & (3.1) & $(21.9)$ & (6.3) & $(34.4)$ & 1.44 \\
\hline 2003 & 22 & $(31.8)$ & $(13.6)$ & (22.7) & $(0.0)$ & $(31.8)$ & 2.95 \\
\hline 2004 & 15 & $(20.0)$ & $(0.0)$ & (33.3) & $(13.3)$ & (33.3) & 1.93 \\
\hline 2005 & 10 & $(40.0)$ & $(10.0)$ & $(20.0)$ & $(0.0)$ & $(30.0)$ & 1.30 \\
\hline 2006 & 19 & $(42.1)$ & $(0.0)$ & $(15.8)$ & $(0.0)$ & $(42.1)$ & 2.16 \\
\hline 2007 & 10 & $(30.0)$ & $(10.0)$ & $(40.0)$ & $(10.0)$ & $(10.0)$ & 2.60 \\
\hline 2008 & 14 & $(71.4)$ & $(7.1)$ & $(0.0)$ & $(0.0)$ & (21.4) & 2.36 \\
\hline 2009 & 9 & $(55.6)$ & $(0.0)$ & (11.1) & $(11.1)$ & $(22.2)$ & 1.89 \\
\hline 2010 & 14 & (71.4) & $(0.0)$ & $(0.0)$ & $(0.0)$ & $(28.6)$ & 1.36 \\
\hline
\end{tabular}

Note: The percentage of each DS outcome that completely ends through DSB proceedings is indicated in parentheses.

Only the officially notified legal proceedings - 'legal-win', 'non-legal win', 'mutually agreed', and 'withdrawal' - are counted as the DSB outcome categories. The remaining statuses that stop at 'no further proceeding' such as 'expired', 'panel not yet been composed' (in particular, more than five years), and 'authority for panel lapsed' are deemed to be a 'dropped' case. It is noted that all these non-litigation cases can occur anytime during the WTO DSB process, even after the WTO legal ruling is made.

Source: Compiled by the author based on sample data.

WTO cases are used for econometric analysis, excluding 103 cases. Out of the 103 cases, 36 cases were related to the exports of respondents (rather than the imports of respondents), and the cases were related to services. Another 57 cases were related to WTO members' general import policies that cannot be linked to specific products in the analysis. The number of observations used in the analysis ranges from 216,176 to 241,946. WTO disputes covered in this sample are 316, with an average of about 120 export partners per respondent per case. Counting the EU as a single member state, the original member countries of the WTO expanded from 113 in 1995 to 141 in 2015.

Although not all exporters exported the disputed products to the respondent initially, in order to consider the overall import demand of the respondent and the 
Table 3. Outcome of WTO DSB filed by agreement category, 1995-2010

Unit: Number (\%)

\begin{tabular}{lrrrrrr}
\hline \hline & & \multicolumn{5}{c}{ WTO DSB outcome } \\
\cline { 3 - 7 } $\begin{array}{l}\text { By } \\
\text { agreement }\end{array}$ & & $\begin{array}{l}\text { Legal- } \\
\text { win }\end{array}$ & $\begin{array}{l}\text { Non- } \\
\text { legal win }\end{array}$ & $\begin{array}{l}\text { Mutually } \\
\text { agreed }\end{array}$ & Withdraw & Dropped \\
\hline Total & 316 & 116 & 20 & 61 & 13 & 106 \\
& $(100)$ & $(36.7)$ & $(6.3)$ & $(19.3)$ & $(4.1)$ & $(33.5)$ \\
AD & 93 & $(37.6)$ & $(2.2)$ & $(14.0)$ & $(2.2)$ & $(44.1)$ \\
CVD/subsidies & 43 & $(48.8)$ & $(4.7)$ & $(4.7)$ & $(2.3)$ & $(39.5)$ \\
SG & 33 & $(21.2)$ & $(12.1)$ & $(33.3)$ & $(3.0)$ & $(30.3)$ \\
Quantitative restrictions & 30 & $(23.3)$ & $(10.0)$ & $(30.0)$ & $(3.3)$ & $(33.3)$ \\
NT (national treatment) & 30 & $(60.0)$ & $(6.7)$ & $(13.3)$ & $(6.7)$ & $(13.3)$ \\
SPS & 26 & $(42.3)$ & $(0.0)$ & $(19.2)$ & $(3.8)$ & $(34.6)$ \\
Customs valuation & 23 & $(39.1)$ & $(8.7)$ & $(13.0)$ & $(13.0)$ & $(26.1)$ \\
TBT & 16 & $(37.5)$ & $(18.8)$ & $(31.3)$ & $(0.0)$ & $(12.5)$ \\
PTA/MFN & 11 & $(9.1)$ & $(0.0)$ & $(45.5)$ & $(0.0)$ & $(45.5)$ \\
DSB & 5 & $(20.0)$ & $(40.0)$ & $(0.0)$ & $(40.0)$ & $(0.0)$ \\
GPA & 3 & $(0.0)$ & $(0.0)$ & $(100.0)$ & $(0.0)$ & $(0.0)$ \\
Import licensing & 3 & $(0.0)$ & $(0.0)$ & $(33.3)$ & $(0.0)$ & $(66.7)$ \\
\hline \hline
\end{tabular}

Note: The percentage of WTO disputes that result in the specific DSB outcome is indicated in parentheses.

Only the officially notified legal proceedings - 'legal-win', 'non-legal win', 'mutually agreed', 'withdrawal', and 'dropped' - are counted as the DSB outcome categories. The 'dropped' category includes cases that stop at 'no further proceeding' such as 'expired,' 'panel not yet been composed' (in particular, more than five years), and 'authority for panel lapsed.' It is noted that all these non-litigation cases can occur at any time during the WTO DSB process, even after the WTO legal ruling is made.

Source: Compiled by the author based on sample data. Agreement categories are used for fixed effect dummies to control for different types of agreement. This categorization is based on 'worldtradlaw.net' and Bown and Reynolds (2015).

total supply of the world exports, all WTO member countries are included in the sample. Trade flow, even when zero, is studied as it provides insight into a country's (firm's) decision to export, or not to export, once trade barriers are removed. To identify the impact of being involved in the dispute in a relative sense, we need to include these non-participant countries as a basis for comparison. Also, our data include all additional exporters outside the WTO membership to test for spillover externalities affecting non-WTO members.

Table 2 provides the number of cases categorized according to the result of the WTO DSB resolutions in each year (1995-2010). Of the observations, 43\% (136 out of 316 cases) went through WTO litigation and received a decision from a panel or $\mathrm{AB}$. Of the cases, $116(36.7 \%)$ are complainant-won cases where respondents were found to be in violation of the WTO rules. Only $6.3 \%$ of respondents were found to be in 'non-violation' once the dispute began in earnest. Such a high winning rate relative to domestic lawsuits appears as a 
distinctive characteristic of international legal conflicts under the WTO dispute settlement system.

Two meaningful inferences can be drawn from this table. The first is that if a complainant decides to launch a legal dispute with the WTO DSB, the case tends to end in favor of the complainant (116 cases, $36.7 \%)$. As likely as legal win cases, many disputes were dropped (106 cases, 33.5\%). The second is that there has been an increasing trend (particularly since 2006) for complainants to be victorious. This trend shows that countries are becoming more cautious and prudent prior to initiating the WTO litigation process, which may reflect an increase in the jurisprudence of the WTO DSB with regards to learning by watching (or learning from rulings) in the system (Ahn, Lee, and Park, 2013; Busch and Reinhardt, 2006; Park, 2016; Shin and Lee, 2013). Meanwhile, the number of cases ended by mutually agreed settlement, and withdrawal is no longer very high and has started decreasing in recent years.

Outcomes from the WTO DSB are classified by trade agreement in Table 3. Disputes concerning anti-dumping (AD) measures make up the largest share of proceedings. Disputes related to trade remedy measures make up about one third of total cases, where the chance of ending a dispute as a legal win for a complainant is relatively high (AD: 38\% and CVD: 49\%) even though $\mathrm{AD}$ disputes have a high rate of dropped cases $(44.1 \%)$. Disputes regarding trade-restrictive measures or related domestic regulations such as national treatment (NT), sanitary and phytosanitary (SPS), custom valuations, and technical barriers to trade (TBT) measures are also high in number and ended with a DSB legal win for the complainants' side. These cases are also often mutually agreed upon or end up being dropped. Finally, import licensing, GPA, DSB, and PTA disputes are the least likely ones to end with a legal win.

\section{Empirical findings}

\subsection{Import changes in post WTO dispute}

This section presents the results of estimation based on the discussions above. Tables 4 and 5 contain the results of the estimation equations (1) and (2), respectively. All estimations with robust standard errors clustered by partner-member countries are in parentheses, controlling for country(member), agreement, industry, and year fixed effects. The trend of each group (complainant, third party, and non-participant) before and after the dispute is fixed to take into account the periodical differences among countries under the DD (difference-in-difference) type of application, presented in Table 4 based on equation (1). Moreover, by defining affected cases (i.e. legal win, non-legal win, mutually agreed, and withdrawal cases) and reference cases (i.e. dropped cases) within each group in the estimations (difference-in-difference-in-difference: DDD), the regression results in Table 5 using equation (2) provide statistical evidence that can shed light on our research question of whether the legal effect of WTO DSB has an impact on trade flow. 
Columns (1)-(8) of Table 4 present the estimates from equation (1), in a relative sense, for the DSB outcome dummy in the sample by measuring the DSB effects during the period from year zero $\left(T_{0}\right)$ up to year three $\left(T_{0}+3\right)$, the time point $\left(T_{0}\right)$ where the dispute completely ends. Columns $(5)-(8)$, in particular, show regression results using respondent time-varying (Respondent $\mathrm{x}$ Year_T) and member time-varying (Member $\mathrm{x}$ Year_T), instead of country time-invariant fixed effects, to account for endogeneity from the omitted variable bias mentioned in Section 3.2. It makes little difference to the results. The WTODS_POST variables are counted based on the notification year $\left(T_{0}\right)$ of the WTO DSB's outcomes categorized as (1) LW: legal win (including AB: Appellate Body ruling), (2) MA: mutually agreed, (3) Non-LW: no legal win, (4) WD: withdrawal, and (5) DROP: dropped cases. DROP cases are used as a reference category. Additionally, a time dummy, WTODS_INI, is used to control for the trend in a dispute initiated year.

The estimation incorporates the WTO dispute-initiated year dummy (WTODS_INI) to show whether there is a difference in trade behavior in the first year of the WTO dispute initiation. In the fifth row, WTODS_INI estimations show that there are statistically significant positive trends in the year of the dispute initiation except for columns (1) and (5), which include the year of WTO dispute completion $\left(T_{0}\right)$. Except for the year effects for the dispute initiation year, there are two reasons to include the WTODS-INI variable in the model: to deal with the issues of (i) reverse causality and (ii) any unusual trade flows during the year of dispute. WTODS_POST captures the post-WTO dispute effect by examining the years after completion of a WTO dispute $[(T+0 \sim 2),(T+$ $1 \sim 2),(T+2 \sim 3)$, or $(T+1 \sim 3)]$. The coefficients on various lagged and durational variables of the WTODS-POST in all columns are positive and significant. According to this result, there is an increase in imports following a dispute's completion.

\subsection{Does the WTO DSB's legal win increase trade overall?}

To analyze the impact of a legal win through the DSB on trade in the years of WTODS_POST based on equation (1), we need to look at the second-order terms (WTODS_POST x DSB dummies). Rows 1- 4 in Table 4 present estimations of the second-order terms. Dependent on the different DSB outcomes, these secondorder terms indicate how much the imports of a respondent (from each source) increase following a dispute's conclusion. When the difference in DSB outcomes is considered, the imports of the LW and Withdrawal cases increase compared to those of the reference case (i.e. Dropped case).

WTODS_POST $\mathrm{x}$ LW (the second-order interaction term capturing the impact of legal winning in the post-dispute period) is significant and positive. This implies that LW cases in the post-WTO DSB dispute years are consistently associated with increases in imports as greater trade growth is expected when the case is pursued than when it is dropped. Specifically, in years subsequent to the WTO 
Table 4. Q1: Legal winning through WTO DSB on trade flow

\begin{tabular}{|c|c|c|c|c|c|c|c|c|}
\hline \multirow[b]{2}{*}{ Dependent variable: lnRIM (real imports) } & \multicolumn{4}{|c|}{ Country fixed effects } & \multicolumn{4}{|c|}{ Country time-varying fixed effects } \\
\hline & $\begin{array}{l}T+0 \sim 2 \\
(1)\end{array}$ & $\begin{array}{l}T+1 \sim 2 \\
(2)\end{array}$ & $\begin{array}{l}T+2 \sim 3 \\
(3)\end{array}$ & $\begin{array}{l}T+1 \sim 3 \\
(4)\end{array}$ & $\begin{array}{l}T+0 \sim 2 \\
(5)\end{array}$ & $\begin{array}{l}T+1 \sim 2 \\
(6)\end{array}$ & $\begin{array}{l}T+2 \sim 3 \\
(7)\end{array}$ & $\begin{array}{l}T+1 \sim 3 \\
(8)\end{array}$ \\
\hline $\begin{array}{l}\beta_{12}^{L W}: \text { WTODS-POST } \mathrm{x} \text { LW } \\
\quad(\text { If WTO DS violation case in WTODS-POST, } 1 \text {; otherwise, } 0 \text { ) }\end{array}$ & $\begin{array}{l}0.099 * * \\
(0.042)\end{array}$ & $\begin{array}{l}0.189 * * * \\
(0.046)\end{array}$ & $\begin{array}{l}0.143 * * * \\
(0.048)\end{array}$ & $\begin{array}{l}0.149 * * * \\
(0.044)\end{array}$ & $\begin{array}{c}0.081^{*} \\
(0.041)\end{array}$ & $\begin{array}{l}0.165 * * * \\
(0.042)\end{array}$ & $\begin{array}{l}0.115 * * \\
(0.045)\end{array}$ & $\begin{array}{l}0.123 * * * \\
(0.040)\end{array}$ \\
\hline $\begin{array}{l}\beta_{12}^{M A}: \text { WTODS_POST } \mathrm{x} \text { MA } \\
\text { (if the WTO DS MA case in WTODS-POST } 1 \text {, otherwise } 0 \text { ) }\end{array}$ & $\begin{array}{l}-0.093 * * \\
(0.042)\end{array}$ & $\begin{array}{r}-0.035 \\
(0.041)\end{array}$ & $\begin{array}{r}-0.062 \\
(0.046)\end{array}$ & $\begin{array}{r}-0.049 \\
(0.041)\end{array}$ & $\begin{array}{l}-0.135 * * * \\
(0.047)\end{array}$ & $\begin{array}{c}-0.077 * \\
(0.046)\end{array}$ & $\begin{array}{l}-0.139 * * * \\
(0.053)\end{array}$ & $\begin{array}{l}-0.110 * * \\
(0.047)\end{array}$ \\
\hline $\begin{array}{l}\beta_{12}^{N L W}: \text { WTODS-POST } \times \text { Non-LW } \\
\quad(\text { If WTO DS not violation case in WTODS-POST, } 1 \text {; otherwise, } 0 \text { ) }\end{array}$ & $\begin{array}{l}0.089 \\
(0.059)\end{array}$ & $\begin{array}{l}0.133 * * \\
(0.062)\end{array}$ & $\begin{array}{c}0.048 \\
(0.066)\end{array}$ & $\begin{array}{c}0.097 \\
(0.061)\end{array}$ & $\begin{array}{l}0.222 * * * \\
(0.066)\end{array}$ & $\begin{array}{l}0.285^{* * *} \\
(0.068)\end{array}$ & $\begin{array}{l}0.210 * * * \\
(0.071)\end{array}$ & $\begin{array}{l}0.227 * * * \\
(0.066)\end{array}$ \\
\hline $\begin{array}{l}\beta_{12}^{W D}: \text { WTODS-POST } \mathrm{x} \text { WD } \\
\text { (If WTO DS withdrawal case in WTODS-POST, } 1 \text {; otherwise, } 0 \text { ) }\end{array}$ & $\begin{array}{l}0.058 \\
(0.039)\end{array}$ & $\begin{array}{l}0.103 * * \\
(0.041)\end{array}$ & $\begin{array}{l}0.100^{* *} \\
(0.038)\end{array}$ & $\begin{array}{l}0.105 * * * \\
(0.037)\end{array}$ & $\begin{array}{c}0.021 \\
(0.042)\end{array}$ & $\begin{array}{l}0.099 * * \\
(0.045)\end{array}$ & $\begin{array}{l}0.098 * * \\
(0.041)\end{array}$ & $\begin{array}{l}0.109 * * * \\
(0.040)\end{array}$ \\
\hline $\begin{array}{l}\text { WTODS-INI }(\tau) \\
\text { (Dispute initiated year: consultation request basis) }\end{array}$ & $\begin{array}{l}-0.019 \\
(0.012)\end{array}$ & $\begin{array}{l}0.065 * * * \\
(0.015)\end{array}$ & $\begin{array}{l}0.067 * * * \\
(0.014)\end{array}$ & $\begin{array}{l}0.066 * * * \\
(0.015)\end{array}$ & $\begin{array}{l}-0.036 * * * \\
(0.013)\end{array}$ & $\begin{array}{l}0.050 * * * \\
(0.015)\end{array}$ & $\begin{array}{l}0.049 * * * \\
(0.014)\end{array}$ & $\begin{array}{l}0.046^{* * *} \\
(0.015)\end{array}$ \\
\hline $\begin{array}{l}\beta_{1}: \text { WTODS-POST } \\
\quad \text { (Years after WTO DS completely ends: } T 0 \sim T+3 \text { ) }\end{array}$ & $\begin{array}{l}0.166^{* * *} \\
(0.023)\end{array}$ & $\begin{array}{l}0.212 * * * \\
(0.030)\end{array}$ & $\begin{array}{l}0.331 * * * \\
(0.036)\end{array}$ & $\begin{array}{l}0.257 * * * \\
(0.032)\end{array}$ & $\begin{array}{l}0.380 * * * \\
(0.057)\end{array}$ & $\begin{array}{l}1.439 * * * \\
(0.069)\end{array}$ & $\begin{array}{l}1.357 * * * \\
(0.079)\end{array}$ & $\begin{array}{l}1.371 * * * \\
(0.071)\end{array}$ \\
\hline $\begin{array}{l}\beta_{2}^{L W}(\mathrm{LW}) \text { : legal winning at WTO dispute } \\
\text { (If WTO DS case is found violation, } 1 \text {; otherwise, } 0 \text { ) }\end{array}$ & $\begin{array}{l}0.028 \\
(0.040)\end{array}$ & $\begin{array}{r}-0.013 \\
(0.040)\end{array}$ & $\begin{array}{r}-0.019 \\
(0.040)\end{array}$ & $\begin{array}{r}-0.020 \\
(0.040)\end{array}$ & $\begin{array}{c}0.029 \\
(0.040)\end{array}$ & $\begin{array}{r}-0.010 \\
(0.040)\end{array}$ & $\begin{array}{r}-0.015 \\
(0.040)\end{array}$ & $\begin{array}{r}-0.016 \\
(0.040)\end{array}$ \\
\hline $\begin{array}{l}\beta_{2}^{M A}(\mathrm{MA}): \text { mutually agreed } \\
\quad(\text { if the WTO DS case is mutually agreed } 1 \text {, otherwise } 0 \text { ) }\end{array}$ & $\begin{array}{l}-0.139 * * \\
(0.059)\end{array}$ & $\begin{array}{l}-0.235 * * * \\
(0.058)\end{array}$ & $\begin{array}{l}-0.224 * * * \\
(0.057)\end{array}$ & $\begin{array}{l}-0.224 * * * \\
(0.058)\end{array}$ & $\begin{array}{r}-0.110 * \\
(0.059)\end{array}$ & $\begin{array}{l}-0.201 * * * \\
(0.058)\end{array}$ & $\begin{array}{l}-0.173 * * * \\
(0.057)\end{array}$ & $\begin{array}{l}-0.175 * * \\
(0.058)\end{array}$ \\
\hline $\begin{array}{l}\beta_{2}^{N L W}(\text { Non-LW): no legal winning } \\
\quad \text { (If WTO DS case is found not violated, } 1 \text {; otherwise, } 0 \text { ) }\end{array}$ & $\begin{array}{l}0.464 * * * \\
(0.071)\end{array}$ & $\begin{array}{l}0.378 * * * \\
(0.072)\end{array}$ & $\begin{array}{l}0.377 * * * \\
(0.076)\end{array}$ & $\begin{array}{l}0.370 * * * \\
(0.074)\end{array}$ & $\begin{array}{l}0.423 * * * \\
(0.073)\end{array}$ & $\begin{array}{l}0.346 * * * \\
(0.074)\end{array}$ & $\begin{array}{l}0.346 * * * \\
(0.077)\end{array}$ & $\begin{array}{l}0.333 * * * \\
(0.075)\end{array}$ \\
\hline $\begin{array}{l}\beta_{2}^{W D}(\mathrm{WD}) \text { : withdrawal } \\
\quad(\text { If WTO DS case is withdrawn, } 1 \text {; otherwise, } 0) \text { ) }\end{array}$ & $\begin{array}{l}-0.160^{* *} \\
(0.079)\end{array}$ & $\begin{array}{l}-0.234 * * * \\
(0.083)\end{array}$ & $\begin{array}{l}-0.226 * * * \\
(0.083)\end{array}$ & $\begin{array}{l}-0.232 * * * \\
(0.083)\end{array}$ & $\begin{array}{r}-0.151^{*} \\
(0.081)\end{array}$ & $\begin{array}{l}-0.229 * * * \\
(0.084)\end{array}$ & $\begin{array}{l}-0.222 * * * \\
(0.083)\end{array}$ & $\begin{array}{l}-0.232 * * * \\
(0.084)\end{array}$ \\
\hline Constant & $\begin{array}{l}-4.958 * * * \\
(0.318)\end{array}$ & $\begin{array}{l}-5.047 * * * \\
(0.320)\end{array}$ & $\begin{array}{l}-5.033 * * * \\
(0.319)\end{array}$ & $\begin{array}{l}-5.095 * * * \\
(0.324)\end{array}$ & $\begin{array}{l}-5.076 * * * \\
(0.316)\end{array}$ & $\begin{array}{l}-5.111 * * * \\
(0.317)\end{array}$ & $\begin{array}{l}-5.071 * * * \\
(0.312)\end{array}$ & $\begin{array}{l}-5.136 * * \\
(0.316)\end{array}$ \\
\hline
\end{tabular}


Table 4. (Cont.)

\begin{tabular}{|c|c|c|c|c|c|c|c|c|}
\hline \multirow[b]{2}{*}{ Dependent variable: lnRIM (real imports) } & \multicolumn{4}{|c|}{ Country fixed effects } & \multicolumn{4}{|c|}{ Country time-varying fixed effects } \\
\hline & $\begin{array}{l}T+0 \sim 2 \\
(1)\end{array}$ & $\begin{array}{l}T+1 \sim 2 \\
(2)\end{array}$ & $\begin{array}{l}T+2 \sim 3 \\
(3)\end{array}$ & $\begin{array}{l}T+1 \sim 3 \\
(4)\end{array}$ & $\begin{array}{l}T+0 \sim 2 \\
(5)\end{array}$ & $\begin{array}{l}T+1 \sim 2 \\
(6)\end{array}$ & $\begin{array}{l}T+2 \sim 3 \\
(7)\end{array}$ & $\begin{array}{l}T+1 \sim 3 \\
(8)\end{array}$ \\
\hline Country fixed effects (respondent/complainant/member) & Yes & Yes & Yes & Yes & & & & \\
\hline Respondent and Member time-varying fixed effects & & & & & Yes & Yes & Yes & Yes \\
\hline Pair-wise fixed effects (respondent-complainant pair) & Yes & Yes & Yes & Yes & Yes & Yes & Yes & Yes \\
\hline agreement fixed effects & Yes & Yes & Yes & Yes & Yes & Yes & Yes & Yes \\
\hline Industry fixed effects (HS Code 2-digit level) & Yes & Yes & Yes & Yes & Yes & Yes & Yes & Yes \\
\hline Year fixed effects & Yes & Yes & Yes & Yes & Yes & Yes & Yes & Yes \\
\hline No. of Obs. (113-138 members x $6 \sim 7$ years x 316 cases) & 240,946 & 216,822 & 216,176 & 254,939 & 240,946 & 216,822 & 216,176 & 254,939 \\
\hline R-square & 0.505 & 0.503 & 0.502 & 0.504 & 0.507 & 0.505 & 0.505 & 0.506 \\
\hline
\end{tabular}

Note: Estimated coefficients based on equation (1) are from least squares regressions. $*$ denotes statistical significance at $10 \%$, $* *$ at $5 \%$, and $* *$ at $1 \%$ level Robust standard errors clustered by member countries are in parentheses. InRIM takes natural log (real import value +1$)$.

WTODS_POST is calculated based on the notification year $\left(T_{0}\right)$ of the WTO DSB's finalized outcomes. The outcomes are categorized into five cases: (1) LW: legal win (including AB: Appellate Body ruling), (2) MA: mutually agreed, (3) Non-LW: no legal win, (4) WD: withdrawal, and (5) DROP: dropped cases. DROP is used as a reference category.

Columns $(5) \sim(8)$ show the regression results using respondent time-varying (Respondent $\mathrm{x}$ Year_T) and membertime-varying $($ Member $\mathrm{x}$ Year_T) instead of country time-invariant fixed effects. 
Table 5. Q2: Effect of legal winning through the WTO DSB on trade flow: who gains more?

\begin{tabular}{|c|c|c|c|c|c|c|c|c|}
\hline \multirow[b]{2}{*}{ Dependent variable: lnRIM (real imports) } & \multicolumn{4}{|c|}{ Country fixed effects } & \multicolumn{4}{|c|}{ Country time-varying fixed effects } \\
\hline & $\begin{array}{l}T+0 \sim 2 \\
(1)\end{array}$ & $\begin{array}{l}T+1 \sim 2 \\
(2)\end{array}$ & $\begin{array}{l}T+2 \sim 3 \\
(3)\end{array}$ & $\begin{array}{l}T+1 \sim 3 \\
(4)\end{array}$ & $\begin{array}{l}T+0 \sim 2 \\
(5)\end{array}$ & $\begin{array}{l}T+1 \sim 2 \\
(6)\end{array}$ & $\begin{array}{l}T+2 \sim 3 \\
(7)\end{array}$ & $\begin{array}{l}T+1 \sim 3 \\
(8)\end{array}$ \\
\hline $\begin{array}{l}\beta_{34}^{L W}: \text { WTODS-POST x LW } \\
\quad \text { (WTO DS violation case in WTODS-POST) }\end{array}$ & $\begin{array}{l}0.116 * * * \\
(0.044)\end{array}$ & $\begin{array}{l}0.205^{* * *} \\
(0.048)\end{array}$ & $\begin{array}{l}0.175^{* * *} \\
(0.050)\end{array}$ & $\begin{array}{l}0.176 * * * \\
(0.046)\end{array}$ & $\begin{array}{l}0.102 * * \\
(0.043)\end{array}$ & $\begin{array}{l}0.186^{* * *} \\
(0.044)\end{array}$ & $\begin{array}{l}0.150 * * * \\
(0.048)\end{array}$ & $\begin{array}{l}0.153 * * * \\
(0.043)\end{array}$ \\
\hline $\begin{array}{l}\beta_{134}^{L W}: \text { WTODS-POST x LW x COMP } \\
\text { (WTO DS LW Effect on Complainant in WTODS-POST) }\end{array}$ & $\begin{array}{c}-0.811 * * \\
(0.347)\end{array}$ & $\begin{array}{r}-0.761 * * \\
(0.353)\end{array}$ & $\begin{array}{l}-1.084 * * * \\
(0.380)\end{array}$ & $\begin{array}{c}-0.999 * * * \\
(0.371)\end{array}$ & $\begin{array}{c}-0.799 * * \\
(0.346)\end{array}$ & $\begin{array}{c}-0.749 * * \\
(0.357)\end{array}$ & $\begin{array}{l}-1.075 * * * \\
(0.382)\end{array}$ & $\begin{array}{l}-0.986 * * * \\
(0.374)\end{array}$ \\
\hline $\begin{array}{l}\beta_{234}^{L W}: \text { WTODS-POST } \mathrm{x} \text { LW } \mathrm{x} \text { THIRD } \\
\text { (WTO DS LW Effect on third-party in WTODS-POST) }\end{array}$ & $\begin{array}{l}-0.816^{* * *} \\
(0.199)\end{array}$ & $\begin{array}{l}-0.591 * * * \\
(0.206)\end{array}$ & $\begin{array}{l}-1.047 * * * \\
(0.261)\end{array}$ & $\begin{array}{l}-0.853 * * * \\
(0.229)\end{array}$ & $\begin{array}{l}-0.805 * * * \\
(0.190)\end{array}$ & $\begin{array}{l}-0.582 * * * \\
(0.205)\end{array}$ & $\begin{array}{l}-1.057 * * * \\
(0.261)\end{array}$ & $\begin{array}{l}-0.834 * * * \\
(0.228)\end{array}$ \\
\hline $\begin{array}{l}\beta_{34}^{M A}: \text { WTODS-POST } \times \text { MA } \\
\text { (WTO DS MA case in WTODS-POST) }\end{array}$ & $\begin{array}{l}-0.061 \\
(0.040)\end{array}$ & $\begin{array}{r}-0.002 \\
(0.040)\end{array}$ & $\begin{array}{c}-0.018 \\
(0.045)\end{array}$ & $\begin{array}{c}-0.010 \\
(0.040)\end{array}$ & $\begin{array}{l}-0.101 * * \\
(0.045)\end{array}$ & $\begin{array}{c}-0.043 \\
(0.045)\end{array}$ & $\begin{array}{r}-0.095^{*} \\
(0.052)\end{array}$ & $\begin{array}{c}-0.070 \\
(0.045)\end{array}$ \\
\hline $\begin{array}{l}\beta_{134}^{M A}: \text { WTODS-POST x MA x COMP } \\
\text { (WTO DS MA Effect on Complainant in WTODS-POST) }\end{array}$ & $\begin{array}{l}-1.544 \\
(0.949)\end{array}$ & $\begin{array}{r}-1.516 \\
(0.949)\end{array}$ & $\begin{array}{l}-1.890 * * \\
(0.899)\end{array}$ & $\begin{array}{r}-1.728^{*} \\
(0.915)\end{array}$ & $\begin{array}{r}-1.460 \\
(0.932)\end{array}$ & $\begin{array}{r}-1.432 \\
(0.932)\end{array}$ & $\begin{array}{l}-1.822 * * \\
(0.890)\end{array}$ & $\begin{array}{r}-1.650 * \\
(0.900)\end{array}$ \\
\hline $\begin{array}{l}\beta_{234}^{M A}: \text { WTODS-POST x MA x THIRD } \\
\text { (WTO DS MA Effect on Third-party in WTODS-POST) }\end{array}$ & $\begin{array}{l}-0.866^{* * *} \\
(0.324)\end{array}$ & $\begin{array}{r}-0.588^{*} \\
(0.329)\end{array}$ & $\begin{array}{l}-1.042 * * \\
(0.417)\end{array}$ & $\begin{array}{l}-0.797 * * \\
(0.370)\end{array}$ & $\begin{array}{l}-0.770 * * \\
(0.335)\end{array}$ & $\begin{array}{r}-0.463 \\
(0.345)\end{array}$ & $\begin{array}{l}-0.920 * * \\
(0.434)\end{array}$ & $\begin{array}{r}-0.675 * \\
(0.386)\end{array}$ \\
\hline $\begin{array}{l}\beta_{34}^{N L W}: \text { WTODS-POST x Non-LW } \\
\text { (WTO DS not violation case in WTODS-POST) }\end{array}$ & $\begin{array}{l}0.104 * \\
(0.060)\end{array}$ & $\begin{array}{l}0.156^{* *} \\
(0.063)\end{array}$ & $\begin{array}{c}0.079 \\
(0.066)\end{array}$ & $\begin{array}{l}0.124 * * \\
(0.061)\end{array}$ & $\begin{array}{l}0.250 * * * \\
(0.068)\end{array}$ & $\begin{array}{l}0.323 * * * \\
(0.070)\end{array}$ & $\begin{array}{l}0.253 * * * \\
(0.072)\end{array}$ & $\begin{array}{l}0.265^{* * *} \\
(0.067)\end{array}$ \\
\hline $\begin{array}{l}\beta_{134}^{N L W}: \text { WTODS-POST x Non-LW x COMP } \\
\text { (WTO DS Non-LW Effect on Complainant in WTODS-POST) }\end{array}$ & $\begin{array}{l}-0.596 \\
(0.587)\end{array}$ & $\begin{array}{l}-0.719 \\
(0.726)\end{array}$ & $\begin{array}{c}-1.082 \\
(0.980)\end{array}$ & $\begin{array}{c}-0.864 \\
(0.818)\end{array}$ & $\begin{array}{r}-0.656 \\
(0.616)\end{array}$ & $\begin{array}{l}-0.770 \\
(0.755)\end{array}$ & $\begin{array}{c}-1.079 \\
(1.020)\end{array}$ & $\begin{array}{r}-0.893 \\
(0.852)\end{array}$ \\
\hline $\begin{array}{l}\beta_{234}^{N L W}: \text { WTODS-POST x Non-LW x THIRD } \\
\text { (WTO DS Non-LW Effect on Third-party in WTODS-POST) }\end{array}$ & $\begin{array}{l}-0.876 * * * \\
(0.319)\end{array}$ & $\begin{array}{l}-0.784 * * \\
(0.356)\end{array}$ & $\begin{array}{l}-0.985 * * \\
(0.424)\end{array}$ & $\begin{array}{l}-0.871 * * \\
(0.384)\end{array}$ & $\begin{array}{l}-0.993 * * * \\
(0.305)\end{array}$ & $\begin{array}{l}-0.937 * * * \\
(0.343)\end{array}$ & $\begin{array}{l}-1.163 * * * \\
(0.409)\end{array}$ & $\begin{array}{l}-1.020 * * * \\
(0.369)\end{array}$ \\
\hline $\begin{array}{l}\beta_{34}^{W D}: \text { WTODS-POST } \mathrm{x} \text { Withdrawal (WD) } \\
\text { (WTO DS withdrawal case in WTODS-POST) }\end{array}$ & $\begin{array}{l}0.059 \\
(0.037)\end{array}$ & $\begin{array}{l}0.106 * * \\
(0.040)\end{array}$ & $\begin{array}{l}0.102 * * * \\
(0.038)\end{array}$ & $\begin{array}{l}0.109 * * * \\
(0.037)\end{array}$ & $\begin{array}{c}0.014 \\
(0.041)\end{array}$ & $\begin{array}{l}0.095 * * \\
(0.044)\end{array}$ & $\begin{array}{l}0.094 * * \\
(0.042)\end{array}$ & $\begin{array}{l}0.107 * * * \\
(0.040)\end{array}$ \\
\hline $\begin{array}{l}\beta_{134}^{W D}: \text { WTODS-POST } x \text { WD x COMP } \\
\text { (WTO DS Non-LW Effect on Complainant in WTODS-POST) }\end{array}$ & $\begin{array}{l}0.561 \\
(0.642)\end{array}$ & $\begin{array}{c}0.184 \\
(0.478)\end{array}$ & $\begin{array}{c}0.251 \\
(0.560)\end{array}$ & $\begin{array}{c}0.191 \\
(0.494)\end{array}$ & $\begin{array}{c}0.560 \\
(0.656)\end{array}$ & $\begin{array}{c}0.185 \\
(0.496)\end{array}$ & $\begin{array}{c}0.210 \\
(0.573)\end{array}$ & $\begin{array}{c}0.163 \\
(0.522)\end{array}$ \\
\hline
\end{tabular}


Table 5. (Cont.)

\begin{tabular}{|c|c|c|c|c|c|c|c|c|}
\hline \multirow[b]{2}{*}{ Dependent variable: $\operatorname{lnRIM}$ (real imports) } & \multicolumn{4}{|c|}{ Country fixed effects } & \multicolumn{4}{|c|}{ Country time-varying fixed effects } \\
\hline & $\begin{array}{l}T+0 \sim 2 \\
(1)\end{array}$ & $\begin{array}{l}T+1 \sim 2 \\
(2)\end{array}$ & $\begin{array}{l}T+2 \sim 3 \\
(3)\end{array}$ & $\begin{array}{l}T+1 \sim 3 \\
(4)\end{array}$ & $\begin{array}{l}T+0 \sim 2 \\
(5)\end{array}$ & $\begin{array}{l}T+1 \sim 2 \\
(6)\end{array}$ & $\begin{array}{l}T+2 \sim 3 \\
\text { (7) }\end{array}$ & $\begin{array}{l}T+1 \sim 3 \\
(8)\end{array}$ \\
\hline $\begin{array}{l}\beta_{234}^{W D}: \text { WTODS-POST } \mathrm{x} \text { WD } \mathrm{x} \text { THIRD } \\
\text { (WTO DS Non-LW Effect on Complainant in WTODS-POST) }\end{array}$ & $\begin{array}{l}0.787^{*} \\
(0.414)\end{array}$ & $\begin{array}{l}0.795 * \% \\
(0.371)\end{array}$ & $\begin{array}{c}0.665 \\
(0.405)\end{array}$ & $\begin{array}{c}0.693^{*} \\
(0.360)\end{array}$ & $\begin{array}{l}0.944 * * \\
(0.406)\end{array}$ & $\begin{array}{l}0.905^{* *} \\
(0.367)\end{array}$ & $\begin{array}{c}0.765^{*} \\
(0.391)\end{array}$ & $\begin{array}{l}0.817 * * \\
(0.347)\end{array}$ \\
\hline Constant & $\begin{array}{l}-4.887^{* * *} \\
(0.313)\end{array}$ & $\begin{array}{l}-4.967 * * * \\
(0.314)\end{array}$ & $\begin{array}{l}-4.947 * * * \\
(0.312)\end{array}$ & $\begin{array}{l}-5.011 * * * \\
(0.318)\end{array}$ & $\begin{array}{l}-5.076 * * * \\
(0.316)\end{array}$ & $\begin{array}{l}-5.111 * * * \\
(0.317)\end{array}$ & $\begin{array}{l}-5.071 * * * \\
(0.312)\end{array}$ & $\begin{array}{l}-5.136 * * \\
(0.316)\end{array}$ \\
\hline $\begin{array}{l}\text { Country fixed effects } \\
\text { (respondent/complainant/member) }\end{array}$ & Yes & Yes & Yes & Yes & & & & \\
\hline $\begin{array}{l}\text { Respondent and Member time-varying } \\
\text { fixed effects }\end{array}$ & & & & & Yes & Yes & Yes & Yes \\
\hline $\begin{array}{l}\text { Pair-wise fixed effects } \\
\text { (respondent-complainant pair) }\end{array}$ & Yes & Yes & Yes & Yes & Yes & Yes & Yes & Yes \\
\hline Agreement fixed effects & Yes & Yes & Yes & Yes & Yes & Yes & Yes & Yes \\
\hline Industry fixed effects (HS Code 2-digit level) & Yes & Yes & Yes & Yes & Yes & Yes & Yes & Yes \\
\hline Year fixed effects & Yes & Yes & Yes & Yes & Yes & Yes & Yes & Yes \\
\hline $\begin{array}{l}\text { No. of Obs. } \\
(113 \sim 138 \text { members } \times 6 \sim 7 \text { years } \times 316 \text { cases })\end{array}$ & 240,946 & 216,822 & 216,176 & 254,939 & 240,946 & 216,822 & 216,176 & 254,939 \\
\hline R-square & 0.520 & 0.518 & 0.517 & 0.518 & 0.522 & 0.520 & 0.519 & 0.520 \\
\hline
\end{tabular}

Note: Estimated coefficients based on equation (2) are from least squares regressions. * denotes statistical significance at $10 \%, * *$ at $5 \%$, and $* * *$ at $1 \%$ level Robust standard errors clustered by member countries are in parentheses. InRIM takes natural $\log$ (real import value +1 ).

WTODS_POST is calculated based on the notification year $\left(T_{0}\right)$ of the WTO DSB's finalized outcomes. The outcomes are categorized into five cases: (1) LW: legal win (including AB: Appallate Body ruling), (2) MA: mutually agreed, (3) Non-LW: no legal win, (4) WD: withdrawal, and (5) DROP: dropped cases.

DROP is used as a reference category.

Participant dummies according to the legal position of WTO DSB are indicated as COMP (complainant), THIRD (third-party); and, non-participants are used as reference group. First- and second-order interaction terms are all included in the estimations, but not reported. Columns (5)-(8) shows the regression result using both respondent time-varying (Respondent x WTODS-POST Year_T) and member time-varying (Member x WTODS-POST Year_T) instead of country timeinvariant fixed effects. 
DSB's ruling implementation, respondents experience higher import values ranging from $8.1 \%$ in column (5) to $18.9 \%$ in column (2). This result is consistent with the argument that once a dispute is initiated and ended with rulings against a respondent's measures, the respondent abides by the decision and removes trade restrictions, allowing greater access to the market (Bown, 2004, 2009; Bown and Reynolds, 2017). While DSB cases that conclude with a legal win are associated with greater levels of trade liberalization, dropped cases tend to be associated with a smaller degree of potential trade liberalization, not just on the bilateral trade level, but also multilaterally.

Particularly when applying country time-varying fixed effects, the coefficients of WTODS_POST x Non-LW and WTODS_POST x Withdrawal WD are also positive and significant. The findings show that when resolving disputes through the formal DSB, the WD increases overall imports compared to the dropped, non-pursued disputes. For the withdrawal cases, the negatively significant coefficient of WD shows that withdrawal cases have lower trade growth than dropped ones, but the overall growth is still positive because of the strongly positive general WTODS-POST effect. This implies that imports increase in the case of WD once the measures at issue go through the dispute settlement system, assuming that officially withdrawing from a case is a voluntary action of complainants (In our study, unofficially reported withdrawal cases are counted as dropped cases). Since the costly WTO disputes are initiated with an official consultation request by complainants, a notification of withdrawal is likely to be announced either when the market access of respondents becomes sufficient or when complainants, at some point during the DSB proceedings, realize that disputed measures are in fact not in violation of WTO rules. Significantly, positive coefficients for WTODS_POST x Non-LW cases seem to be peculiar, given that Non-LW cases are thought to involve disputed measures at issue and are subject to more stringent legal contest. However, even Non-LW may offer greater legal clarity and so encourage trade by providing a clear interpretation of WTO rules previously subject to dispute. Trade is likely to grow if disputed measures are found to be consistent with WTO agreements, as with Non-LW outcomes. In summary, as opposed to dropped cases, disputes officially resolved as LW, Non-LW, or withdrawal under the WTO DSB lead, on average, to increases in imports from all WTO members in respondent markets and favor multilateral trade liberalization.

Under the DSB system, disputes ending in officially mutually agreed solutions are associated with significant import decreases. Mutual settlements can be made both before and after the WTO ruling, and cases can be ended both with and without official notification. However, in this analysis, only officially announced mutually agreed cases are included. The total number of mutually agreed cases which are used in this estimation is 61 , as shown in Tables 2 and 3. In cases where parties seek to end the dispute by settlement in order to reduce legal costs, mutual agreements are usually made right after the initiation of a dispute, within a year of the 
consultation request. ${ }^{8}$ Parties, for example, may choose to agree to withdraw from the WTO DSB proceedings to enjoy exclusive bilateral benefits. Thus, mutually agreed cases are usually expected to have a positive benefit for the complainant; otherwise, legal proceedings would continue. However, mutual agreements may also limit bilateral trade liberalization and work favorably for respondents. In short, both cases may promote only bilateral trade flows, not multilateral trade liberalization. It is for this reason that our empirical framework estimates a significantly negative MA coefficient.

\subsection{Who gains more from the rulings?}

The following results focus on our second empirical question of which group is most benefited by the efficacy of DSB outcomes. If we can find a systematic variation in the trade gains of different participant groups following disputes, this could help to understand the overall utility of the system from the perspective of legal contestants. Table 5 shows the results of regressions based on equation (2) when different legal participants are included as the complainant and the third party (with complainant, third party, vs. non-participants as a reference group) with a full model using a three-level interaction of DSB dummies.

Table 5, in the second and third rows under WTODS_POST x LW, displays different legal effects according to the legal status of dispute participants relative to the effect for non-participants.

The first noteworthy points are the third-order interaction terms $\left(\beta_{134}\right.$ : WTO_POST x LW x COMP) and ( $\beta_{234}$ : WTO_POST x LW x THIRD). They show what happens to the imports from the complainant and third party groups to the respondents relative to imports from non-participants when the WTO case is legally won. In all columns (1)-(8) of Table 5, the coefficients appear to be strongly significant and negative. There are apparently smaller proportional trade gains from the WTO DSB's rulings for the major legal stakeholders (complainants and/or third-parties) than for non-participants. ${ }^{9}$ This interpretation is more precise when viewed with the second-order interaction term: WTODS_POST $\mathrm{x}$ LW (which captures the impact of a legal win in the post dispute period) and the three-order interaction term: WTODS_POST x LW x COMP (or THIRD). WTODS_POST $\mathrm{x}$ LW is very significant and positive with a large coefficient.

8 Except for four cases (EC-Bananas III (DS27); US-Softwood Lumber III (DS236); EC-Approval and Marketing of Biotech Products (DS291, 292, 293)), legal proceedings for all mutually agreed cases did not exceed three years. Although there are several cases in which parties officially reported mutual agreements after the panel or AB rulings, even those cases were closed within a short period of time, with the rulings made within a year or two.

9 Although the proportional gains of legal participants are smaller, their absolute gains per country are far larger because their initial trade levels are so much larger: by about 20 times (THIRD) and 35 times (COMP) - see table 1. In fact, the fixed effects for COMP and THIRD in equation (2) suggest that, allowing for other factors, these flows are even larger relative to average, see Table A4 in the online appendix. 
This implies that a legal win leads to economic gains (i.e., import liberalization of the respondent) once the DSB ruling (LW) is implemented. However, the gains are more greatly distributed to non-participating WTO members rather than to the complainant and third party groups. The statistically significant and negative coefficients of $\beta_{134}$ (WTO_POST x LW x COMP) and $\beta_{234}$ (WTO_POST x LW $\mathrm{x}$ THIRD) indicate that the distribution of gains between groups is less favorable for legal contestants. For instance, the sum of the two coefficients $\left(\beta_{34}^{L W}\right.$ : WTO_POST $\mathrm{x}$ LW and $\beta_{134}^{L W}$ : WTO_POST $\mathrm{x}$ LW $\mathrm{x}$ COMP) represents the effect for COMP, as a complainant group (for the effect for THIRD would be the sum of $\beta_{34}^{L W}$ and $\beta_{134}^{L W}$ : WTO_POST x LW x THIRD). Using the estimated coefficients of column (1) for COMP, a precise interpretation is that when a ruling is made against the respondent, the complainant experiences, on average, a $50 \%$ (= $\left.\mathrm{e}^{0.116-0.811}-1\right)$ smaller proportional increase in trade (exports to respondents) than do non-participants during years $(T+0 \sim 2)$ after a dispute ends.

As discussed in Section 2, the results above may be attributable to the multilateral nature of the WTO system. The MFN principle is a cornerstone for effective trade liberalization in the WTO system. It allows even free riding for non-participant countries to benefit from legal wins and gain new exporting opportunities. Our results reaffirm Ludema and Mayda's (2009) findings on this free-rider problem in relation to WTO MFN externalities. Evidence of the free-rider problem becomes apparent following a legal win for a complainant (LW), when a disputed market becomes more open and competitive (less concentrated) than before. ${ }^{10}$

The econometric results of Table 5 are in line with the results of Table 4. For the complainants, the proportional additional benefits from the WTO DSB proceedings appear to be relatively small. From each complainant's viewpoint, however, the expected trade gains may not be insignificant considering the absolute level of trade involved and the counterfactual of not contesting a case (actual declines in trade); hence, it may still remain rational to take a complainant to the WTO dispute settlement system. Through WTO disputes, complainants do indeed prevent further trade damage and increase their exports. ${ }^{11}$ We find that, so long

10 The question of whether or not concentrated exporters deepen liberalization of respondent's import markets is discussed in Section 5.4 and backed up by evidence from the sub-sample of major exporters and $\mathrm{AD} / \mathrm{CVD}$ dispute cases.

11 Although this study focuses more on the multilateral trade impact of the DSB rulings, our findings also shed light on the motivation of member countries for pursuing DSB legal rulings and their apparent disregard for DSB free riding. Table 1 helps to provide an understanding of the motivation for participating complainants. The average rates of export growth for complainants in post-dispute years (e.g. 30.6 41.1\% in the LW case) seem to be slightly smaller than those of non-participants $(29.1 \sim 52.1 \%)$. Yet, absolute values of each individual complainant's exports (e.g. exports increase from 1,101 to 1,437 million USD) should be divided by 10 or fewer complainants on average. Therefore, more than 30 million USD should be rewarded to each exporter involved, a value roughly five times bigger than the exports of individual non-participants $(23 \rightarrow 29$ million USD: $\Delta 6)$. As in this example, trade gains depend on how many participants or complainants are involved in a dispute. If there is only one complainant, individual export gains for the complainant following a DSB ruling will be far greater than for any other country. This 
as a legal win can result in significant liberalization of the respondent's market and raise total imports for respondents (WTO_POST x LW), complainants and third parties do not necessarily lose their markets. It is simply noted that the proportional trade benefits to other parties are relatively larger than the gains earned by those involved in the legal proceedings.

The results for mutually agreed cases in Table 5 show negatively significant coefficients for both WTODS_POST x MA x COMP and WTODS_POST x MA $\mathrm{x}$ THIRD, especially in column $(3) /(4)$ and $(7) /(8)$, indicating that there are no direct benefits to either the complainant or third party. This suggests that mutual settlements may prevent trade liberalization not only between agreed parties but for others as well, as shown in column (7) of Table 5. Rather, mutual settlements seem to hamper the multilateral trade liberalizing effect of the WTO DSB. In contrast to legal winning cases, mutually agreed cases appear to result in neither multilateral liberalization nor increased exports for complainants or third parties.

\subsection{Further robustness checks and other issues ${ }^{12}$}

In the previous sections, we account for changes in the number of WTO members by assuming that all WTO members are possible beneficiaries from the DSB's rulings. Although not all WTO members have significant economic interests in the products at issue, the inclusion of all exporters that hold WTO membership is important for considering new entry of bilateral trade between the respondent and potential exporters. The following robustness checks are designed to dispel the notion that our results simply reveal the dominance of a large number of small exporters with greater extensive/intensive margin growth relative to a small number of major pre-existing exporters that sell in large volumes.

In this section, we conduct a robustness exercise, first, to extend the DSB effects to non-WTO members and, second, to restrict the impact of the DSB to only 'major' exporters. The main findings are that LW cases are associated with trade creation not only from the extensive margin growth for non-WTO members, but also from the intensive margin growth for even non-participants.

To confirm these points, columns (1) to (3) of Table A1 present overall LW DSB effects on trade after the dispute using DD type estimation, while columns (4) to (6) estimate DSB effects according to legal participatory status in the dispute. First, columns (1) and (4) examine the spillover effects of the DSB on ROW (Rest of World). The results of DD and DDD show similar patterns to those in Tables 4 and 5. Second, columns $(2) /(3)$ and $(5) /(6)$, which restrict the data sample to sets of 'major exporters' defined respectively as lying within the top 25 or 10 percentiles

explains the high incidence of WTO disputes over AD/CVD matters, where the structure of the export market is usually highly concentrated and generally monopolistic. More empirical evidence for this is included in tables of the online appendix.

12 Refer to the online appendix for the regression results. 
of all exporters, suggest that our main findings on the overall trade effects of LW captured by second level interaction terms remain robust and are more or less consistent in the third level interaction terms. In the third level interaction terms, however, the coefficients of the third parties in columns $(5) /(6)$ are no longer statistically significant.

In the previous pooled sample of all countries, trade liberalization levels are different following a dispute, especially in cases where the WTO DSB's ruling(s) find the respondent to be in violation. This result turns out to be statistically significant and negative for complainant/third party groups, meaning that in a relative sense, the non-participant group experiences more positive gains. To further check the sensitivity of the overall results, we proceed to another set of regressions by excluding three countries (China, US, and EU) along with AD/CVD dispute cases.

First, the rationale for excluding the sub-samples of the three WTO members is that average and growth of China's exports may be significantly different from other WTO member countries. Also, China has demonstrated rapid export growth and experienced relatively large increases in respondent markets after rulings, whereas the US and EU have been the most frequent users of the WTO DSB as both complainants and respondents.

Second, one of the main concerns is that our results only capture trade diversion effects, rather than trade creation from the rulings. For example, when AD or CVD duties are imposed, other players may replace major exporters in the market - an effect which should not be seen as a trade gain resulting from DSB rulings. Accordingly, we check whether the LW effect is still valid when excluding AD/ CVD cases, bearing in mind that AD/CVD cases account for a significant portion of all WTO disputes (approximately 40\%). This robustness-check using a subgroup analysis also helps us to verify whether multilateral liberalizing effects also result from removing National Treatment-type non-discriminatory measures after DSB rulings.

Table A2 shows that excluding the AD/CVD sub-group does not change the previous pattern of trade creation. Excluding the AD/CVD sub-group, trade creation from LW effects remains unchanged in the post-dispute years. The rest of the results for the three interaction terms are very similar, though the coefficients in the No-US and No-AD/CVD equations become larger. This means that the market re-adjustment effects, created by the elimination of trade-restrictive features of the NT measures (other than AD/CVD), may generate smaller gains for complainants and larger gains for non-participants. In the sub-group that excludes the US as a respondent, negatively larger coefficients in column (2) and (6) imply that the US has a stronger than average resistance to market liberalization.

Our findings are consistent with the findings of Ludema and Mayda (2009, 2013). They argue that GATT/WTO exporting countries have incentives to free ride due to the so-called MFN externality. Connecting WTO MFN tariff-negotiation to trade liberalization, their empirical evidence shows that the higher the import concentration is in a certain product, the greater the market access and 
import growth that result from the tariff negotiation. Bown and Reynolds (2017) also suggest that the free-rider problem prevails when sectors involve a concentrated number of exporting countries. If WTO dispute settlement is considered as a form of trade liberalizing negotiation, our empirical results on the WTO DSB's LW outcome and import growth are consistent with the findings of Bown and Reynolds (2017) and Ludema and Mayda (2009, 2013).

Table A1 presents the size of estimated coefficients from the sub-sample of Major 10th percentile exporters. The coefficient values in column (3) for WTODS_POST $\mathrm{x}$ LW are greater than those for less concentrated exporters in the sub-samples of Major 25th percentile and ROW (Rest of World). In addition, given that AD/CVD cases tend to occur in relatively concentrated sectors such as automobile, steel, and electronics sectors, the free-riding problem is expected to be reduced. Our results in Table A2 provide support for this hypothesis. When excluding AD/CVD disputes in the sample, the coefficient estimate of WTODS_POST $\mathrm{x}$ LW is the smallest compared to other models, indicating that AD/CVD disputes involve lower competition. In other words, trade gains from DSB rulings are small when excluding these disputes. The estimated results also show that the complainants and third parties make lesser gains than non-participants.

By using only AD/CVD cases, we have conducted another robustness analysis. Table A3 shows that the free-riding problem seems to be weaken in AD/CVD disputes where import markets tend to be more highly concentrated. It is noted that when complainants win a dispute, they reap the biggest trade gain among other exporters: WTODS-POST x LW x COMP is significantly positive. Interestingly, mutually agreed cases provide the most trade gains for complainants, a result which differs from previous regression results that use the full sample. When restricting the analysis sample to AD/CVD cases, DSB disputes ending with a mutually agreed solution (MA) involves a seemingly less free rider problem. As Table A3 shows, the effects of the WTO DSB possibly depend on the behavior of exporters that may vary by sector and agreement. This study, however, has not allowed for such heterogeneity in sector and agreement as it would require precise and sufficient data to do so (Conconi et al., 2017).

\section{Conclusion}

The WTO DSB has been praised for its improvement and development of institutional aspects compared to the GATT system. We investigate the impact of the WTO DSB in relation to the trade flow of products at issue by revisiting the role of the DSB's multilateral institutional mechanism.

Our analysis is performed across three different dimensions: (i) change before and after the dispute; (ii) variation according to the result of the rulings; and (iii) variation among different legal participants. The empirical analysis suggests that a legal win brings a greater proportional increase in trade to non-participants than to the complainant/third party countries. To minimize statistical noise, we 
focus on trade flow changes within a two- or three-year period following a dispute's completion and use various timing points to capture the WTO DSB's effects. While most other researches have studied bilateral trade flows, our analysis examines the WTO DSB's effects by raising the possibility of MFN externalities and explores the implications for the world economy as a whole. Thus, our result highlights the multilateral nature of the WTO dispute settlement system.

It should be noted that our results do not merely capture trade diversion effects that are typically shown by the studies on trade remedy disputes. The trade diversion effect of trade remedy measures differs from the DSB effects discovered in our findings in that overall trade gains are created in the latter cases. As demonstrated in the robustness section, additional gains are extended to 'non-disputed' countries. Moreover, the increased trade value for each non-participant may be small but, when combined, the total trade creation is larger for non-participants than for legal participants. Despite the asymmetry in relative gains between legal participants and non-participants, legal participants stand to individually attain absolute gains and prevention of further trade damage to existing export levels. Thus, participants still have sufficient economic incentives to pursue DSB proceedings until a complete win. Furthermore, the complainant may also receive benefits from the legal sense - a reputation for litigious behavior that leads to better access to other markets.

In addition to litigated disputes, our study also examined non-litigated DSB cases. Surprisingly, our findings suggest that mutually agreed cases are not associated with trade increases, at either the multilateral or bilateral levels. One might expect a bilaterally agreed solution to automatically lead to certain mutual benefits after a settlement; however, the regression results found no direct economic benefits related to mutually agreed cases. In fact, trade flows decreased for all legal participants as well as non-participants. This result seems to imply that mutually agreed cases involve more or less 'desperate' situations in which the disputing parties are forced to choose a restriction of imports instead of more general trade liberalization, possibly for political benefit (Conconi et al., 2017).

We may draw some policy implications for the current WTO DSB amendment process as well as interpretations of the efficacy of the WTO DSB's rulings on market access from this analysis. Our findings emphasize the nexus between legal wins and economic gains, especially a persistent free-riding problem. Since complainants have more incentives to end disputes by mutual settlement rather than DSB ruling due to the free-riding problems, the whole WTO system may suffer from early resolution of disputes by losing the chance for the multilateral trade creation effect of DSB rulings. This economic finding clearly runs counter to the conventional legal understanding and practices for preferring mutual settlement to litigation. But the experiences of the WTO DSB so far seem to raise a question about whether the current consultation process should be promoted or even maintained at least from the economic point of view. We hope our analysis helps to further address the role of the WTO DSB as a platform for multilateral trade liberalization. 


\section{Supplementary Material}

To view supplementary material for this article, please visit https://oi.org/10.1017/ S1474745617000544.

\section{References}

Ahn, D., J. Lee, and J.-H. Park (2013), 'Understanding non-litigated disputes in the WTO Dispute Settlement system', Journal of World Trade, 47(5): 985-1012.

Ahn, D. and W. Shin (2011), 'Analysis of anti-dumping use in free trade agreements', Journal of World Trade, 45(2): 431-456.

Baier, S. L. and J. H. Bergstrand (2007), 'Do free trade agreements actually increase members' international trade?', Journal of International Economics, 71(1): 72-95.

Bagwell, K. and R. W. Staiger (1999), 'An economic theory of GATT', American Economic Review, 89(1): 215-248.

— (2001), 'Domestic policies, national sovereignty, and international economic institutions', The Quarterly Journal of Economics, 116(2): 519-562.

_ (2005), 'Enforcement, private political pressure, and the General Agreement on Tariffs and Trade/ World Trade Organization escape clause', The Journal of Legal Studies, 34(2): 471-513.

Bechtel, M. M. and T. Sattler (2015), 'What is litigation in the World Trade Organization worth?', International Organization, 69(02): 375-403.

Bown, C. P. (2004), 'On the economic success of GATT/WTO Dispute Settlement', The Review of Economics and Statistics, 86(3): 811-823.

- (2009), Self-Enforcing Trade: Developing Countries and WTO Dispute Settlement, Brookings Institution Press.

Bown, C. P. and K. M. Reynolds (2015), 'Trade flows and trade disputes', The Review of International Organizations, 10(2): 145-177.

— (2017), 'Trade agreements and enforcement: evidence from WTO dispute settlement', American Economic Journal: Economic Policy, 9(4): 64-100.

Busch, M. L. and E. Reinhardt (2006), 'Three's a crowd: third parties and WTO dispute settlement', The World Politics, 58(3): 446-477.

Busch, M. L., E. Reinhardt, and G. Shaffer (2009), 'Does legal capacity matter? A survey of WTO Members', World Trade Review, 8(4): 559-577.

Bütler, M. and H. Hauser (2000), 'The WTO dispute settlement system: a first assessment from an economic perspective', Journal of Law, Economics, and Organization, 16(2): 503-533.

Chaudoin, S., J. Kucik, and K. Pelc (2016), 'Do WTO disputes actually increase trade?', International Studies Quarterly, 60(2): 294-306.

Ceva, E. and A. Fracasso (2010), 'Seeking mutual understanding: a discourse-theoretical analysis of the WTO Dispute Settlement System', World Trade Review, 9(3): 457-485.

Conconi, P., D. R. DeRemer, G. Kirchsteiger, L. Trimarchi, and M. Zanardi (2017), 'Suspiciously timed trade disputes', Journal of International Economics, 105, 57-76.

Davis, C. L. (2012), 'Why Adjudicate? Enforcing Trade Rules in the WTO', Princeton, NJ: Princeton University Press.

Davis, C. L. and S. B. Bermeo (2009), 'Who files? Developing country participation in GATT/WTO adjudication', The Journal of Politics, 71(3): 1033-1049.

Donald, S. G. and K. Lang (2007), 'Inference with difference-in-differences and other panel data', The Review of Economics and Statistics, 89(2): 221-233.

Helpman, E., M. Melitz, and Y. Rubinstein (2008), 'Estimating trade flows: trading partners and trading volumes', The Quarterly Journal of Economics, 123(2): 441-487.

Hoekman, B., H. Horn, and P. C. Mavroidis (2008), Winners and Losers in the Panel Stage of the WTO Dispute Settlement System (No. 769), IFN Working Paper. 
Horn, H. and P. C. Mavroidis (2008), 'The WTO Dispute Settlement Data Set 1995-2006', World Bank, http:siteresources.worldbank.orgINTRESResources469232-1107449512766DisputeSettlement DataManual, 3062008.

Imbens, G. and J. M. Wooldridge (2007), 'What's new in econometrics?', NBER.

— (2009), 'Recent developments in the econometrics of program evaluation', Journal of Economic Literature, 47(1): 5-86.

Keck, A. and S. Schropp (2008), 'Indisputably essential: the economics of dispute settlement institutions in trade agreements', Journal of World Trade, 42(5): 785-812.

Kucik, J. and K. Pelc (2016), 'Measuring the cost of privacy: a look at the distributional effects of private bargaining', British Journal of Political Science, 46(4): 861-889.

Ludema, R. D. and A. M. Mayda (2009), 'Do countries free ride on MFN?', Journal of International Economics, 77(2): 137-150.

- (2013), 'Do terms-of-trade effects matter for trade agreements? Theory and evidence from WTO Countries', The Quarterly Journal of Economics, 128(4): 1837-1893.

Maggi, G. and R. W. Staiger (2011), 'The role of dispute settlement procedures in international trade agreements', The Quarterly Journal of Economics, 126(1): 475-515.

Park, J. H. (2016), 'Enforcement and dispute settlement', Handbook of Commercial Policy, vol.1(part B), 3-67.

Sattler, T. and T. Bernauer (2011), 'Gravitation or discrimination? Determinants of litigation in the World Trade Organisation', European Journal of Political Research, 50(2): 143-167.

Shin, W. and D. Ahn (2017), Firm's responsive behaviors in WTO trade disputes: countervailing cases on Korean DRAMs, Journal of World Trade, 51(4): 605-644.

Shin, W., K. Lee, and W. G. Park (2016), When an importer's protection of IPR interacts with an exporter's level of technology: comparing the impacts on the exports of the north and south', World Economy, 39(6): 772-802.

Shin, W. and W. Lee (2013), 'Legality of R\&D subsidies and its policy framework under the world trading system', STI Policy Review, 4(1): 27-53. 